\title{
National Radiobiology Archives Distributed Access User's Manual
}

\author{
C. R. Watson \\ J. C. Prather \\ S. K. Smith
}

November 1991

Prepared for the U.S. Department of Energy under Contract DE-AC06-76RLO 1830

Pacific Northwest Laboratory Operated for the U.S. Department of Energy by Battelle Memorial Institute 


\section{LEGAL NOTICE}

This report was prepared by Battelle as an account of sponsored research activities. Neither Sponsor nor Battelle nor any person acting on behalf of either:

MAKES ANY WARRANTY OR REPRESENTATION, EXPRESS OR IMPLIED, with respect to the accuracy, completeness, or usefulness of the Information contained in this report, or that the use of any Information, apparatus, process, or composition disclosed in this report may not infringe privately owned rights; or

Assumes any liabilities with respect to the use of, or damages resulting from the use of, any information, apparatus, process, or composition disclosed in this report.

Reference herein to any specific commercial product, process, or service by trade name, trademark, manufacturer, or otherwise, does not necessarily constitute or imply endorsement, recommendation, or favoring by Sponsor or Battelle.

\section{NOTICE}

This document was produced with Government support under Contract Number DE-AC06-76RLO 1830 awarded by the United States Department of Energy. The Government has certain rights in the information and data contained herein.

This software package may be run under Paradox Runtime (Copyright 1990, Borland International, all rights reserved). End users who run NRA Distributed Access under Paradox Runtime agree to the following:

- acknowledge that Paradox Runtime is owned by Borland International and may not be copied,

- look to PNL, the application developer, and not Borland International, for any support services required by this application,

- take no action against Borland International for any damages resulting from the use of this application, it being understood that Paradox Runtime is provided by Borland International "AS IS" and without warranties or liabilities for any damages. 
PNL -7877

DE92 003914

\title{
NATIONAL RADIOBIOLOGY ARCHIVES
}

\section{Distributed Access}

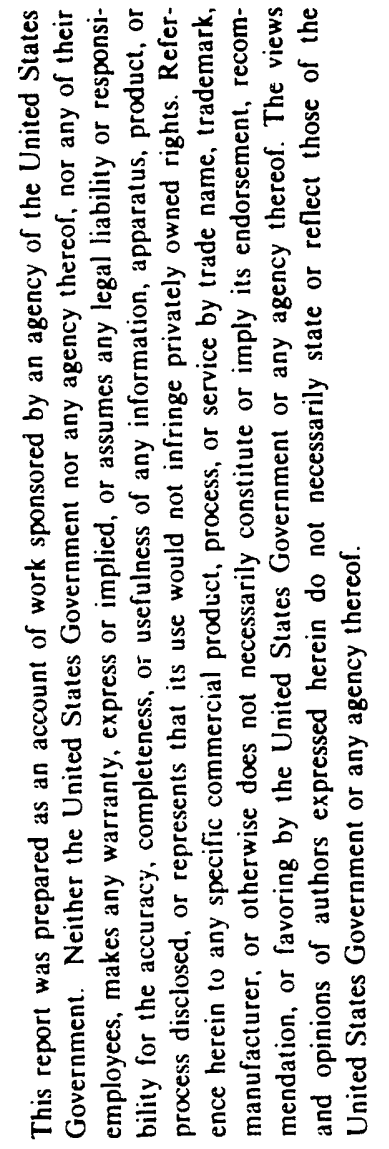

\author{
Version 1.0 \\ USER'S MANUAL
}

November 1991

Chuck Watson

Jonathan Prather

Sean Smith

Pacific Northwest Laboratory

Richland, Washington 99352

Linfield College

McMinnville, Oregon 97128 


\section{LEGAL NOTICE}

This report was prepared by Battelle as an account of sponsored research activities. Neither Sponsor nor Battelle nor any person acting on behalf of either:

MAKES ANY WARRANTY OR REPRESENTATION, EXPRESS OR IMPUED, whth respect to the accuracy, completeness, or usefulness of the Information contained in this report, or that the use of any information, apparatus, process, or composition disclosed in this report may not infringe privately owned rights; or

Assumes any llabllities with respect to the use of, or damages resulting froin the use of, any information, apparatus, process, or composition disclosed in this report.

Reference herein to any specific commercial product, process, or service by trade name, tradernark, manufacturer, or otherwise, does not necessarily constitute or imply endorsement, recommendation, or favoring by Sponsor or Battelle.

\section{NOTICE}

This document was produced with Government support under Contract Number DE-AC06-76RLO 1830 awarded by the United States Department of Energy. The Government has certain rights in the information and data contained herein.

This software package may be run under Paradox Runtime (Copyright 1990, Borland International, all rights reserved). End users who run NRA Distributed Access under Paradox Runtime agree to the following:

- acknowledge that Paradox Runtime is owned by Borland International and may not be copied,

- look to PNL, the application developer, and not Borland International, for any support services required by this application,

- take no action against Borland International for any damages resulting from the use of this application, it being understood that Paradox Runtime is provided by Borland International "AS IS" and without warranties or liabilities for any damages. 
Installing the Software

Starting NRA Distributed Access
If you are reasonably comfortable working in the DOS environment and have access to an IBM PC/AT or better microcomputer with 3.5 megabytes of hard disk storage available, you may install and use NRA Distributed Access without recourse to the remainder of this manual.

To install the software, insert the diskette labeled NRA Distributed Access 1 in a floppy disk drive and type:

\section{A:INSTALL A: C:}

where A: is the name of the source floppy disk drive and $C:$ is the name of the target hard disk drive.

You must invoke NRA Distributed Access from the INRA subdirectory on the hard disk. Move to the subdirectory by typing:

\section{INRA}

To start NRA Distributed Access using Paradox ${ }^{\oplus}$ Runtime, type:

\section{NRA}

You should see the NRA Distributed Access title screen:

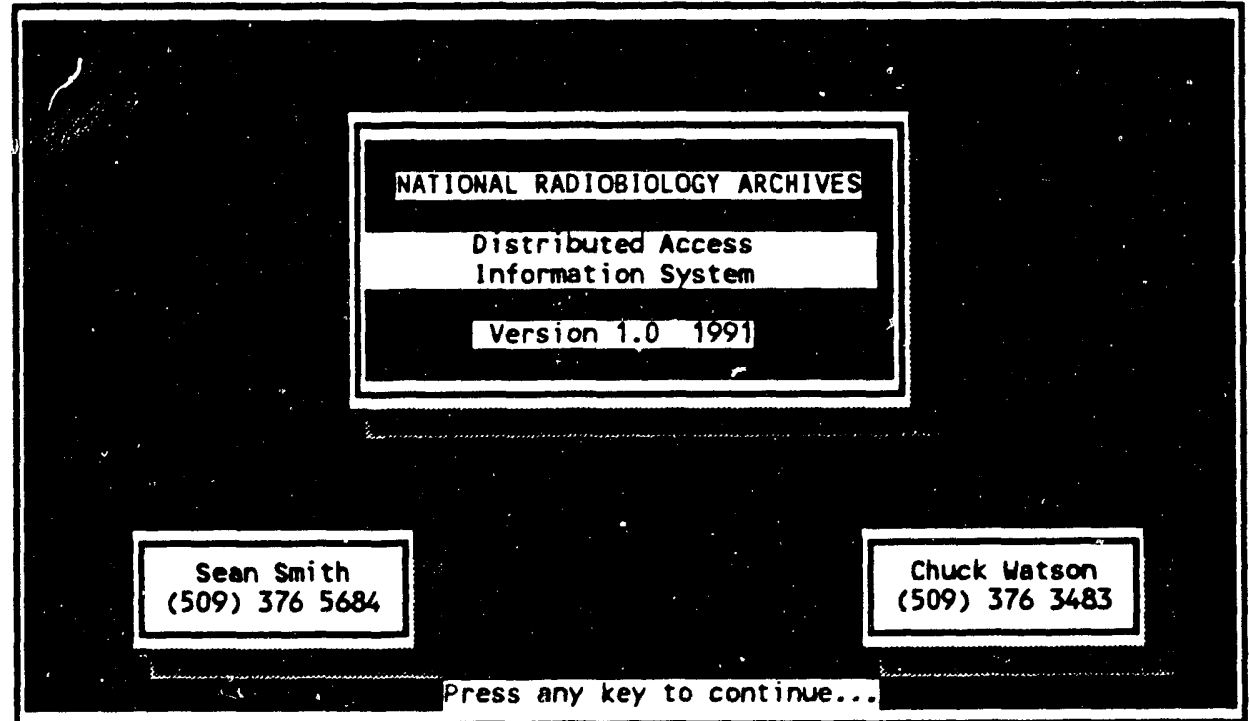


License Agreement $\ldots \ldots \ldots \ldots \ldots \ldots \ldots \ldots$ ii

Quick Start $\ldots \ldots \ldots \ldots \ldots \ldots \ldots \ldots \ldots \ldots \ldots \ldots$ iii

Installing the Software $\ldots \ldots \ldots \ldots \ldots \ldots \ldots$ iii

Starting NRA Distributed Access $\ldots \ldots \ldots \ldots \ldots \ldots \ldots$ iii

Table of Contents $\ldots \ldots \ldots \ldots \ldots \ldots \ldots \ldots \ldots \ldots$

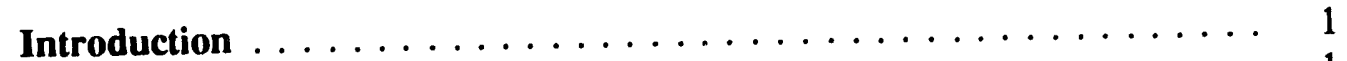

What is the NRA? . . . . . . . . . . . . . . 1

Information Distribution Philosophy $\ldots \ldots \ldots \ldots \ldots \ldots$

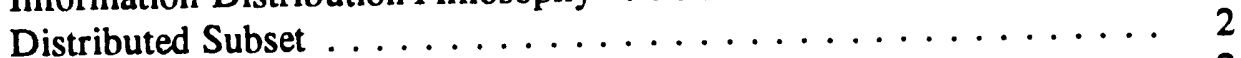

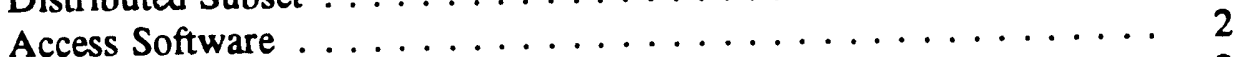

Other Subsets . . . . . . . . . . . . . . . . 2

Conventions Used in this Manual . . . . . . . . . . . . 3

Scope and Purpose of User's Guide . . . . . . . . . . . . 3

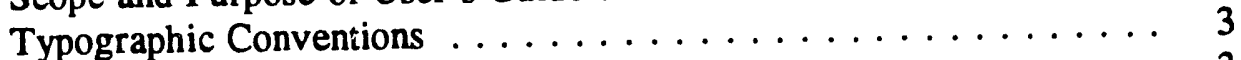

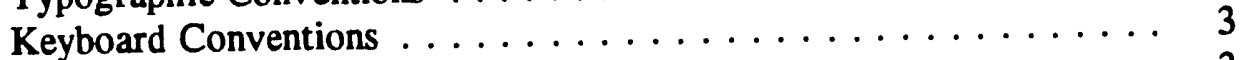

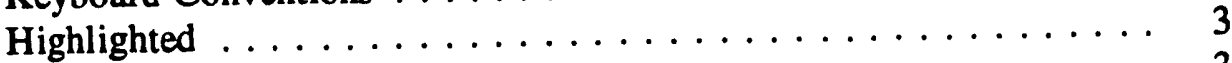

Trademarks $\ldots \ldots \ldots \ldots \ldots \ldots \ldots \ldots \ldots \ldots \ldots \ldots \ldots$

Software Distribution $\ldots \ldots \ldots \ldots \ldots \ldots \ldots \ldots \ldots \ldots$

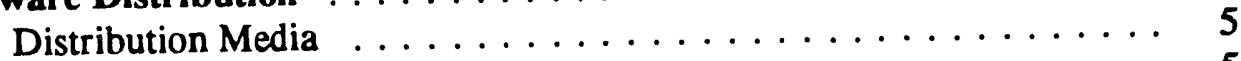

Software Package Contents $\ldots \ldots \ldots \ldots \ldots \ldots \ldots \ldots \ldots$

Distribution via NESC $\ldots \ldots \ldots \ldots \ldots \ldots \ldots \ldots \ldots \ldots$

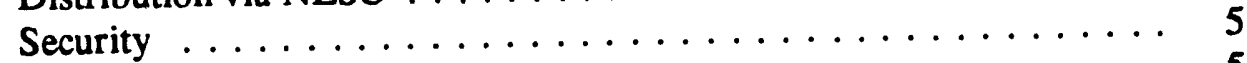

Error Reporting and Assistance $\ldots \ldots \ldots \ldots \ldots \ldots \ldots \ldots$

Computing Environment $\ldots \ldots \ldots \ldots \ldots \ldots \ldots \ldots$

Hardware $\ldots \ldots \ldots \ldots \ldots \ldots \ldots$

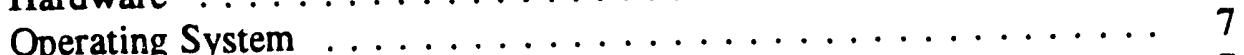

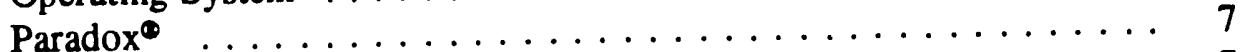

Paradox $^{\oplus}$ versus Paradox ${ }^{\oplus}$ Runtime Execution $\ldots \ldots \ldots \ldots \ldots$

INRA ........................ 7

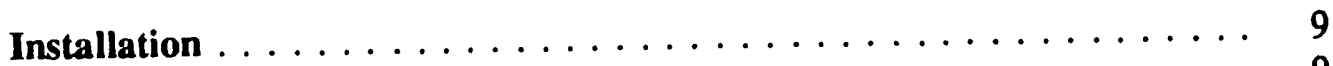

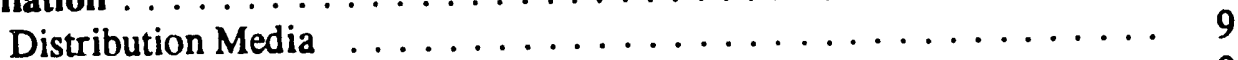

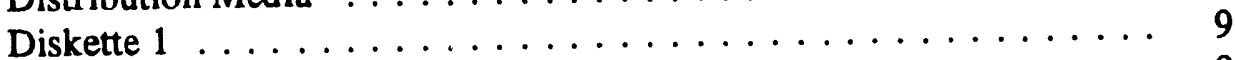

If you change your mind $\ldots \ldots \ldots \ldots \ldots \ldots$

What if subdirectory NRA is already there? . . . . . . . . 10

Install confirmation display $\ldots \ldots \ldots \ldots \ldots \ldots \ldots$

Prompt for next diskette $\ldots \ldots \ldots \ldots \ldots \ldots \ldots \ldots \ldots$

Diskette $2 \ldots \ldots \ldots \ldots \ldots \ldots \ldots \ldots \ldots$

Running NRA Distributed Access $\ldots \ldots \ldots \ldots \ldots$

NRA Dirtribured Access 
Using Paradox ${ }^{\oplus u n t i m e ~ a s ~ s u p p l i e d ~} \ldots \ldots \ldots \ldots \ldots \ldots \ldots$

Using your own copy of Paradox ${ }^{\oplus} \ldots \ldots \ldots \ldots \ldots \ldots$

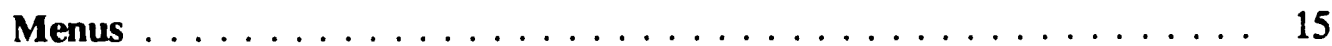

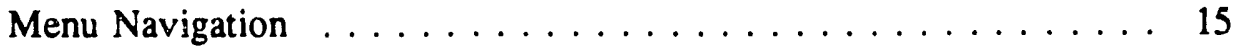

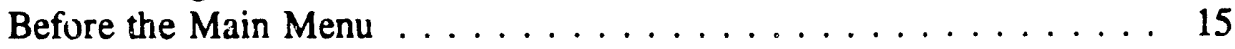

Title Screen . . . . . . . . . . . . . . . . . . . 15

License Agreement Screen $\ldots \ldots \ldots \ldots \ldots \ldots \ldots \ldots$

Paradox $^{\oplus}$ Runtime Disclaimer $\ldots \ldots \ldots \ldots \ldots \ldots \ldots$

Menu Structure . . . . . . . . . . . . . . . . . . . 17

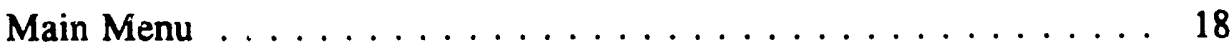

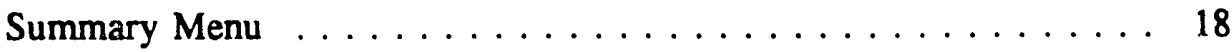

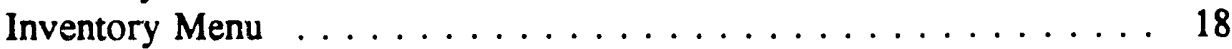

Bibliography Menu . . . . . . . . . . . . . . . 19

Summary Database Search Menu . . . . . . . . . . . . 20

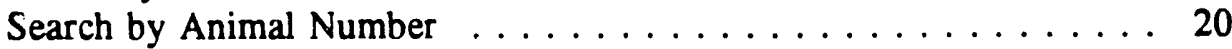

F1 option shows list of animals $\ldots \ldots \ldots \ldots \ldots \ldots \ldots \ldots$

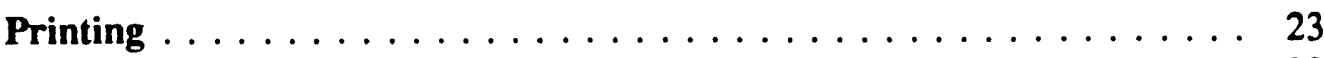

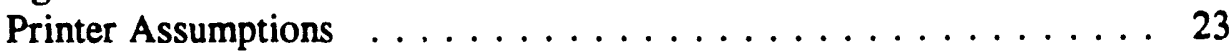

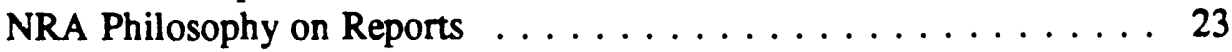

Summary Database Browse - Print option, F6 . . . . . . . . 24

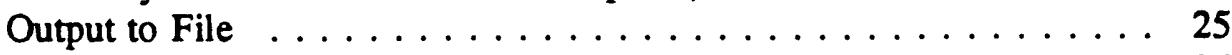

Output to Printer . . . . . . . . . . . . . . . . 26

Animal Summary Report example . . . . . . . . . . . . 27

Report shows more than screen $\ldots \ldots \ldots \ldots \ldots \ldots \ldots \ldots \ldots$

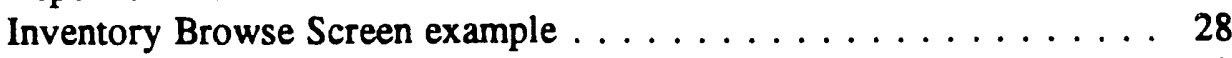

Inventory Report example . . . . . . . . . . . . . . . . 29

Bibliography Browse Screen example . . . . . . . . . . . 30

Bibliography Report example . . . . . . . . . . . . . 31

NRA Information Systems $\ldots \ldots \ldots \ldots \ldots \ldots \ldots \ldots \ldots$

Types of Information Available $\ldots \ldots \ldots \ldots \ldots \ldots \ldots$

Active disk storage $\ldots \ldots \ldots \ldots \ldots \ldots \ldots \ldots \ldots \ldots$

Summary Database ................... 33

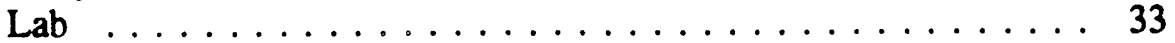

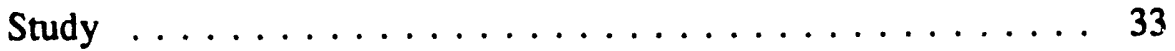

Group ........................ 34

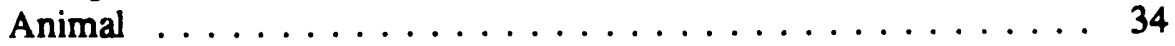

Tissue Dose . . . . . . . . . . . . . . . . 34

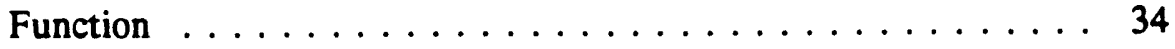

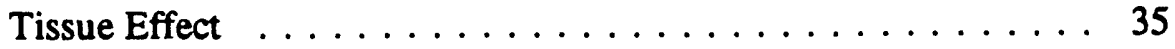

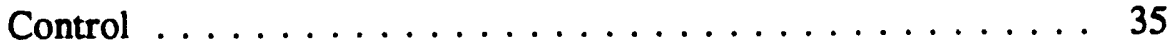

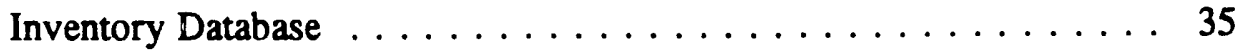

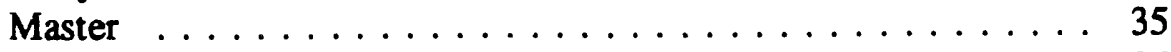

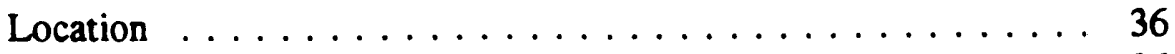

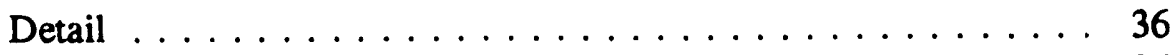

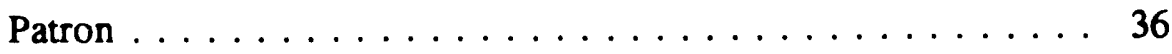

Loan ...................... 36

Bibliography Database $\ldots \ldots \ldots \ldots \ldots \ldots \ldots \ldots \ldots \ldots$

Book . . . . . . . . . . . . . . . . . 36 


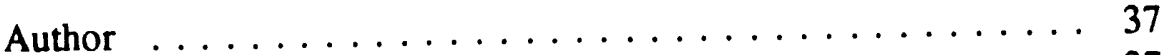

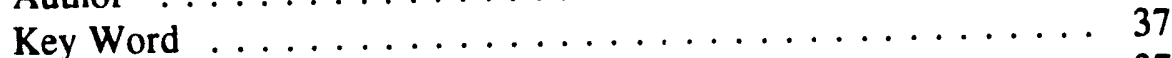

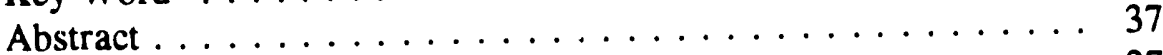

Detailed Database Tables . . . . . . . . . . . . . . 37

Distributed Subset $\ldots \ldots \ldots \ldots \ldots \ldots \ldots \ldots \ldots \ldots \ldots \ldots$

Selection of the Introductory subset $\ldots \ldots \ldots \ldots \ldots \ldots \ldots \ldots$

Disk Storage Requirements . . . . . . . . . . . . . . . . . . 39

Summary Database Subset . . . . . . . . . . . . . . . . . 39

Lab $\ldots \ldots \ldots \ldots \ldots \ldots \ldots$

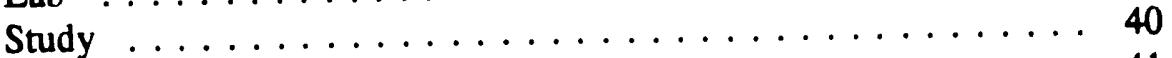

Group $\ldots \ldots \ldots \ldots \ldots \ldots \ldots \ldots \ldots \ldots \ldots \ldots$

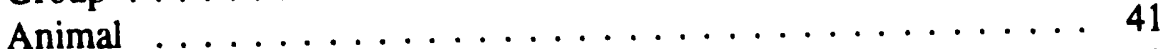

Tissue Effect $\ldots \ldots \ldots \ldots \ldots \ldots \ldots \ldots \ldots \ldots \ldots \ldots \ldots$

Tissue Dose . . . . . . . . . . . . . . . . . . 43

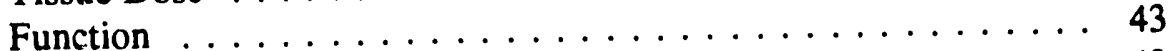

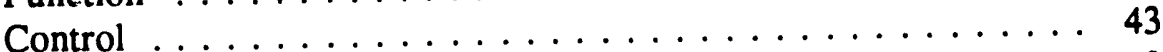

Inventory Database Subset $\ldots \ldots \ldots \ldots \ldots \ldots \ldots \ldots \ldots$

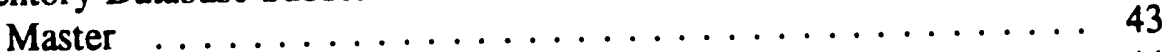

Location ...................... 44

Detail ....................... 45

Loan $\ldots \ldots \ldots \ldots \ldots \ldots \ldots \ldots \ldots \ldots \ldots \ldots$

Patron ....................... 46

Bibliography Database Subset $\ldots \ldots \ldots \ldots \ldots \ldots \ldots \ldots \ldots$

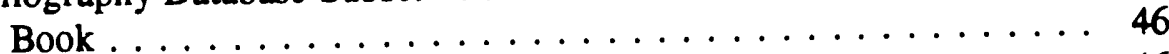

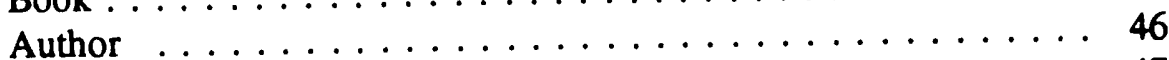

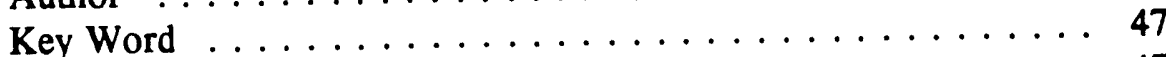

Abstract . . . . . . . . . . . . . . . . 47

Menu Help $\ldots \ldots \ldots \ldots \ldots \ldots \ldots \ldots \ldots \ldots \ldots \ldots \ldots \ldots \ldots$

Bibliography ..................... 49

Cursor Control ...................... 50

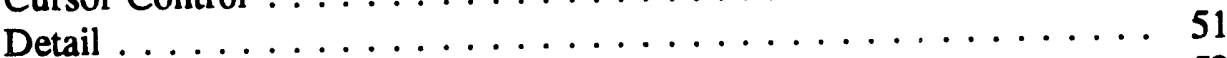

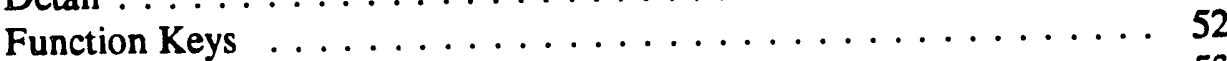

$\ldots \ldots \ldots \ldots \ldots \ldots \ldots \ldots$

NRA $\ldots \ldots \ldots \ldots \ldots \ldots \ldots \ldots \ldots$

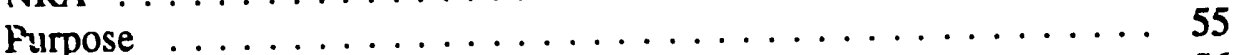

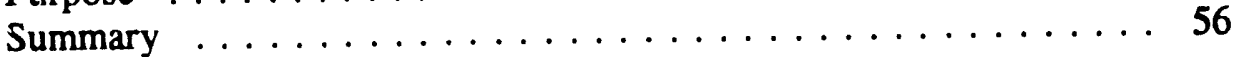

Cursor Related Help . . . . . . . . . . . . . . . . . . . 59

Accession date $\ldots \ldots \ldots \ldots \ldots \ldots$

Animal ID . . . . . . . . . . . . . . . . 59

Animal Quantity ..................... 59

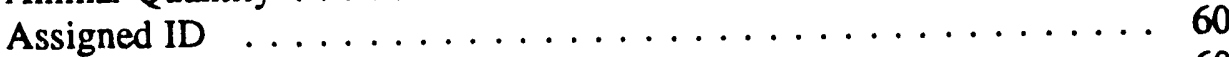

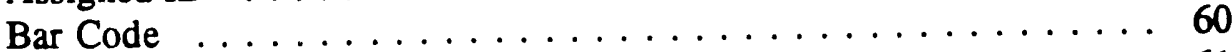

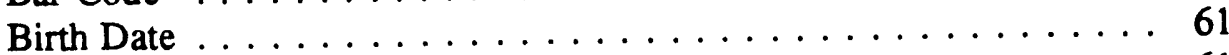

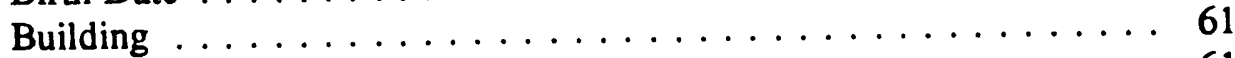

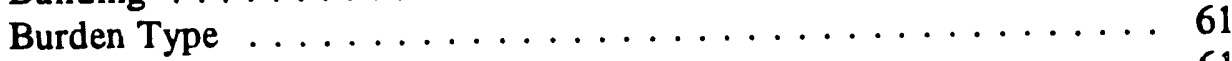

Cabinet ........................ 61

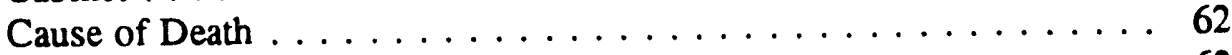

Comments ........................ 62 


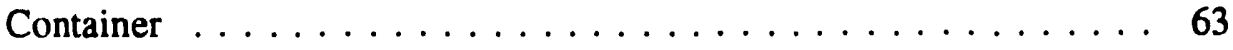

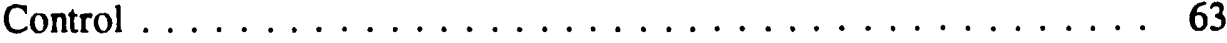

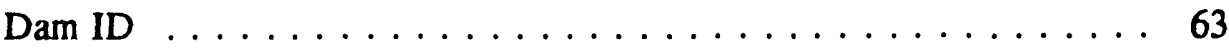

Death Date . . . . . . . . . . . . . . . . 63

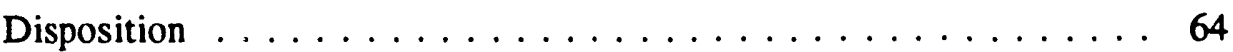

Document Type ..................... 64

Donor Identification $\ldots \ldots \ldots \ldots \ldots \ldots \ldots \ldots$

Final Insult Date . . . . . . . . . . . . . . . . . . . . 64

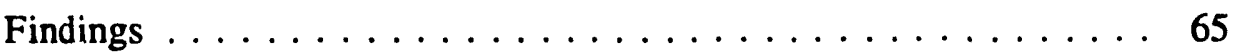

First Insult Date $\ldots \ldots \ldots \ldots \ldots \ldots \ldots \ldots \ldots \ldots \ldots$

First Name . . . . . . . . . . . . . . . . . . 65

Group Identification . . . . . . . . . . . . . . . . . 66

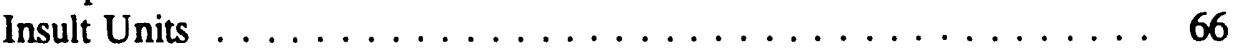

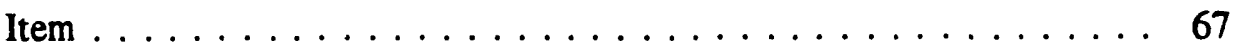

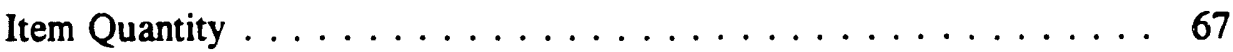

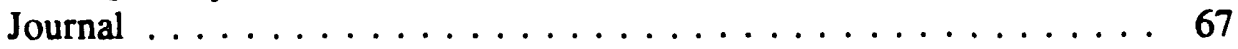

Lab . . . . . . . . . . . . . . . . . . . 67

Laboratory Identification $\ldots \ldots \ldots \ldots \ldots \ldots \ldots$

Last Name . . . . . . . . . . . . . . . . . . 68

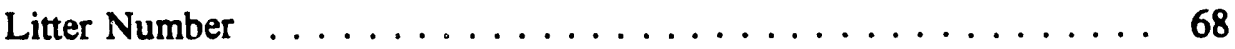

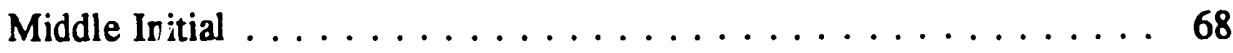

Morphology Category $\ldots \ldots \ldots \ldots \ldots \ldots \ldots \ldots \ldots$

No Help Available . . . . . . . . . . . . . . . . . . . 69

Pages . . . . . . . . . . . . . . . . . . . . 69

Position ........................ 69

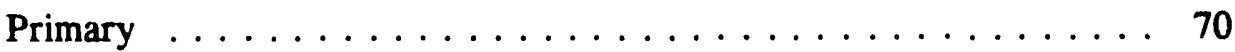

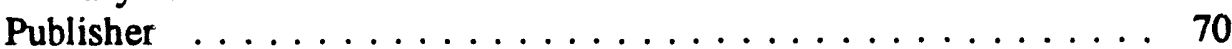

Publication Year . . . . . . . . . . . . . . . . 70

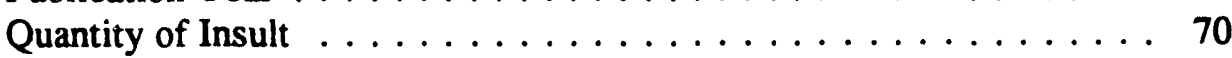

Qualifier .......................... 70

Quantity .......................... 71

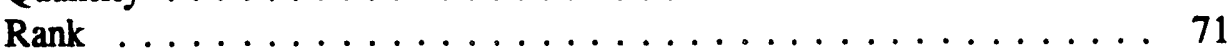

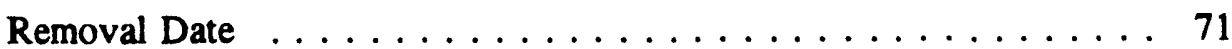

Report Number .................... 71

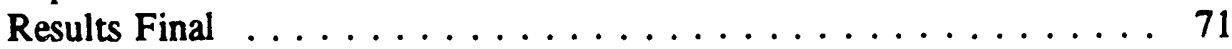

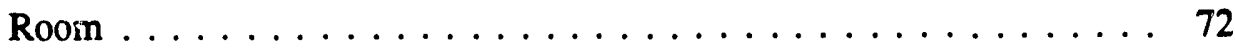

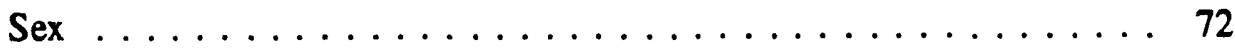

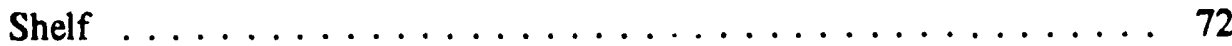

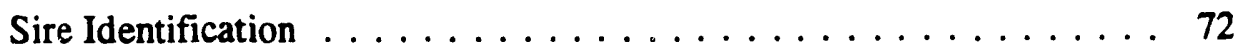

Snodog . . . . . . . . . . . . . . . . . . . 73

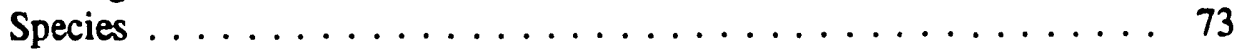

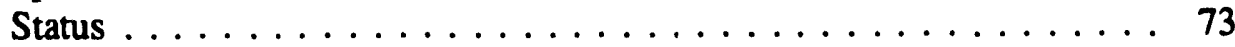

Study Identification $\ldots \ldots \ldots \ldots \ldots \ldots \ldots \ldots \ldots \ldots \ldots$

Sub Title . . . . . . . . . . . . . . . . . . . . . 74

Tissue Category . . . . . . . . . . . . . . . 74

Tissue Quality . . . . . . . . . . . . . . . 74

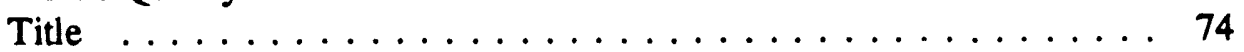

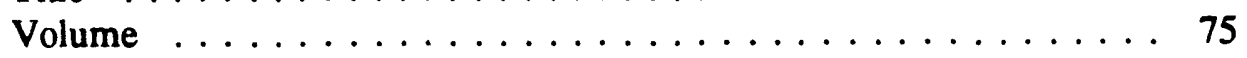

Weight at First Insult $\ldots \ldots \ldots \ldots \ldots \ldots \ldots \ldots \ldots \ldots$ 
This User's Manual describes installation and use of the National Radiobiology Archives (NRA) Distributed Access package. The package consists of a distributed subset of information representative of the NRA databases and database access software which provide an introduction to the scope and style of the NRA Information Systems.

What is the NRA?
The National Radiobiology Archives is a comprehensive effort to gather, organize, and catalog original data, representative specimens, and supporting materials related to significant radiobiology studies. This provides researchers with infeimation for analyses which compare or combine results of these and other studies and with materials for analysis by advanced molecular biology techniques. The NRA concentrated initially on studies of beagle dogs exposed to ionizing radiation at Argonne National Laboratory (ANL), the Inhalation Toxicology Research Institute (ITRI), the Pacific Northwest Laboratory (PNL), the University of California at Davis (DAVIS), and the University of Utah (UTAH). Rodent studies, primarily those conducted at Oak Ridge National Laboratory (ORNL) and at ANL are being added. The NRA will be receiving a donation of information from the life-span study of beagle dogs conducted at Colorado State University (CSU).

The NRA uses a three task approach to the challenge of organizing material from diverse sources. The microcomputer based NRA Information Systems include: experimental design documentation, animal does-effect summaries, laboratory specific detailed datahases, bibliographic citations, and an inventory of the documents and specimens. The NRA works closely with database managers at the participating laboratories to insure that electronic information is accurately translated into the NRA format. The initial donation to the NRA Document Archives is the collection of reprints and other materials supporting his book Radioactivity and Health, A History by J. Newell Stannard. The NRA Specimen Archives has tissue specimens and histopathology blocks from more than 1000 dogs donated by DAVIS. The specimens are organized and housed in a protected environment. These databases and archives are maintained through bar code readable labels.

Computer database technology is essential to integrating such a broad and diverse collection of information. The NRA Information Systems has developed several inter-related databases, each of which follows the relational model. There are three major databases: the Dose-effects Summary, the Collection Inventory, and the Bibliography. These are commonly referred to as the SUMMARY, INVENTORY, and BIBLIOGRAPHY databases and are illustrated in the NRA Distributed Access package. In addition, the information systems contains many detailed database tables. These are copies of laboratory specific files translated from various computers and information management systems to the microcomputer environment and a comn.on database management system. These DETAILED databases are not included in the NRA Distributed Access package. 
Information

Distribution

Philosophy

\section{Distributed}

Subset

Access Software

Other Subsets
Information in the NRA Summary, Inventory, and Bibliography database is available on request. Printed reports have been provided in the past. The completion of the NRA Distributed Access package is the realization of a long standing goal of the NRA staff and advisory committee. Now, information may be easily distributed to the user in an electronic form which preserves the relationships between the various database tables.

In the future, a subser of requested information will be extracted by the NRA staff and placed on diskette along with the access software. This user's manual and the diskette(s) will be sent to the information requester.

NRA Distributed Access package includes a representative subset of the extensive NRA Information Systems database maintained at the Pacific Northwest Laboratory. The introductory subset consists of summary records for 100 control animals from various laboratories. It also contains 100 typical records from the bibliographic citation database. Inventory records showing the location of animal specimens and cited documents are also included. The introductory subset is described on page 39.

The Distributed Access menus, forms, and reports are independent of the dataset. They comprise a relational database management system configured especially for the National Radiobiology Archives. It is designed to show the scope of the system by allowing the user to browse records with the databases' associated main forms. Several simple searches have been included to illustrate potential data extractions. Printed reports may be produced.

The Distributed Access system is menu driven, and on-screen help is available at all times.

Other subsets, or the full NRA Information Systems database, may be accessed through menus provided with the NRA Distributed Access package. The NRA will select and distribute subsets of information upon request. 
Scope and Purpose of User's Guide

Typographic Conventions

Keyboard Conventions

Highlighted

Trademarks
This document is designed for the user. The manual includes: an overview of the NRA distributed access concept, a discussion of hardware requirements, instructions for installing and executing the software on the user's computer, descriptions and examples of menus, instructions for printing reports of database contents, a description of the database tables and alphabetized reference sections. A companion document, NRA Distributed Access Programmer's Manual describes details of the implementation.

When you are instructed to use the keyboard, the keys will be in bold italics. Most keys are identified by the characters on the keyboard. The spacebar is always shown as Spacebar. Note that some keyboards use Page $U_{p}$ and/or $P g U p$ and Page Down and/or PgDn. These sets of keys are functionally equivalent.

Text you are instructed to enter appears as large bold type. Commands are shown in UPPER CASE and must be typed exactly as shown. Lower case input indicates user-specified names or text. All input lines are terminated by pressing the Enter key.

When instructed to use the keyboard, the keys are identified by name, (e.g., Enter) with the exceptions of the Spacebar and the arrow keys. The arrow keys are identified as Up Arrow, Down Arrow, Right Arrow, and Left Arrow. When two keys are to be pressed simultaneously, the plus sign is used, (e.g., Control +Break).

The keys which control movement of the cursor on the screen are collectively called the cursor control keys.

The function keys are called $F 1, F 2, F 3, \ldots$

Throughout this user's guide, the word highlighted refers to text and areas which are emphasized (with more contrast) to stand out from their surroundings. When something is highlighted it usually means it is selected or is about to be chosen.

The IBM PS/2 and AT, and DOS are products of International Business Machines Corp, P.O. Box 1328, Boca Raton, Florida 33429-1328.

Paradox is a registered trademark of Borland International, 1800 Greenhills Road, P.O. Box 660001, Scotts Valley, California 95066-0001. 
Distribution

Media

\section{Software \\ Package \\ Contents}

Distribution via NESC

Security

Error Reporting and Assistance
NRA Distributed Access is supplied on either 3-1/2 inch (1.44 megabyte) or 5$1 / 4$ inch (1.2 megabyte) high-density floppy diskettes formatted under PC DOS. The diskettes are labelled NRA Distributed Access 1 and NRA Distributed Access 2.

An automated procedure controls installation of the software onto the host computer's hard disk. The software is provided in compressed format and a public domain utility is used to decompress the software.

Distribution of the NRA Distributed Access package (software and introductory subset of the NRA database), in accordance with DOE Order 1360.4A (10-7-

87) is through the National Energy Software Center (NESC). Requests for this software may be made to:

\section{Director \\ National Energy Software Center \\ Argonne National Laboratory \\ 9700 South Cass Avenue \\ Argonne, Illinois 60439}

NESC will provide users notice of updates to the NRA Distributed Access package when they become available.

Maintenance of the integrity and confidentiality of the software package and associated subject data files is the responsibility of the user. No special provisions for accessibility of the program or data files are included in the software package.

If you have any unexplained error messages while running NRA Distributed Access or if you need assistance, please contact:
Sean Smith
Pacific Northwest Laboratory
Post Office Box 999 P7-82
Richland, WA 99352
Phone: (509) 376-5684
FAX: $\quad(509) 376-4533$ 
Hardware

Operating

System

Paradox ${ }^{\circ}$

Paradox versus
Paradox
Runtime
Execution

INRA
The NRA Distributed Access package may be implemented on any $\mathrm{IBM}^{\oplus} \mathrm{PS} / 2$, AT or fully-compatible computer configured with either a 5-1/4 inch or 3-1/2 inch high density floppy disk drive. A minimum of 3.5 megabytes of available on-line disk storage is necessary to install the software. A minimum of 512 kilobytes of RAM should be available. If printed reports are desired, a printer must be available to the computer.

This software will execute under DOS 3.3 or later version.

The NRA Distributed Access system, as well as the primary NRA Information Systems were developed in Paradox ${ }^{\circ}$, a database management product of Borland International. The NRA Distributed Access menus operate through the runtime application version of Paradox ${ }^{\oplus}$. The license from Borland to Pacific Northwest Laboratory allows unlimited distributed of such runtime applications. Use of the NRA Distributed Access package does not require Paradox ${ }^{\oplus}$ ownership or usage skills.

NRA Distributed Access menus may also be run under Paradox ${ }^{\bullet}$ Version 3.5. Users who have a licensed copy of Paradox ${ }^{\bullet}$ on their computer may wish to take advantage of the ad hoc query facility, via F10 ASK, to explore retrieval strategies not supported in the NRA Distributed Access search menus.

Paradox ${ }^{\oplus}$ users may also access alternative report and screen formats associated with the tables which are not available under the runtime application. Instructions for accessing NRA Distributed Access from Paradox ${ }^{\circ}$ will be found on page 13 .

The directory INRA and its subdirectories contain the distributed subset of database tables and the access mechanism consisting of the Paradox ${ }^{\bullet}$ Runtime software, scripts and help text. This relationship between access software and database information is shown by hading the access software in the following diagram. 
NRA directory tree

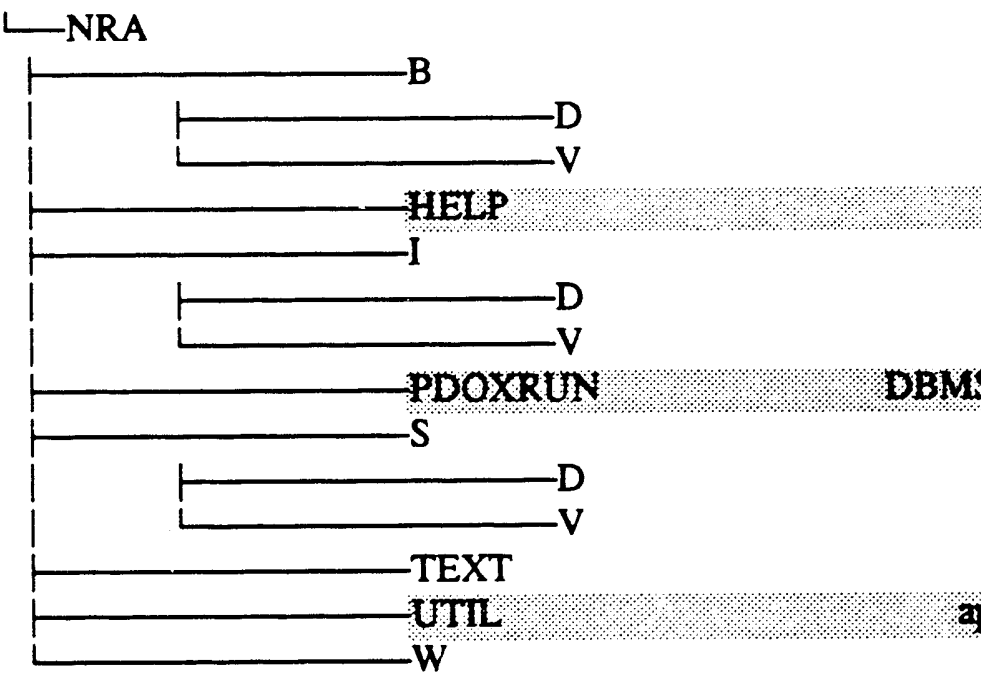

root

bibliography node

data tables

validation tables text files inventory node data tables validation tables BUS numine sof tware summary node data tables validation tables clinical files application software work files 
Distribution Media

Diskette 1

If you change your mind
NRA Distributed Access package is supplied on two or more diskettes. The installation process will expand the compressed datah ase and software and move it to the hard disk. You will need approximately 3,500,000 bytes oif free disk space. If you have multiple disk partitions on your computer, you must choose where to place the NRA Distributed Access package. These instructions are for installing from A: to C:. In the instructions below, you may substitute $B$ for $A$ and some other hard disk drive letter for $C$.

Insert the diskette labeled NRA Distributed Access 1 in the drive. Invoke the INSTALL.BAT program on the diskett:. You must supply two drive identifiers to the install program. The first is the letter of the diskette drive, the second is the letter of the destination drive.

\section{C: > A:IINSTALL A: C:}

You will see the following screen:

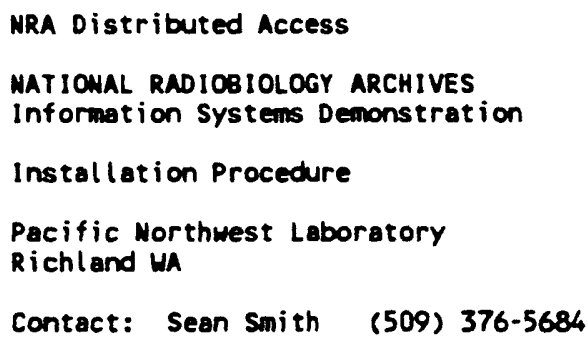

If you do not want to proceed with the installation, enter Control +Break to abort the process. You may abort at any time in the installation process.

If you strike any key except Control + Break the installation process will start. 
Several directories will be built on the hard disk. The root directory for this application is called NRA.

What if subdirectory NRA is already there?

Install confirmation display
If there is already a directory called NRA on your hard disk, you will see the following screen:

copy of NRA Distributed Access already exists on $c$

Compressed NRA Distributed Access will overwrite existing version on $c$ :

Press CONTROL-BREAK to cancel overwrite

If you press any key except Control + Break, the installation process will start. If you press Control +Break, the process will stop. You may then take decide how to proceed.

Once you have started the installation process, you will see the names of the expanded files as they are moved from the diskette to the hard disk. The screen will look something like the following:

Press CONTROL-BREAK if this is incorrect.

Strike a key when ready. .

200: nra.bat -- extracted

200: disp.do -.. extracted

200: disp.f1 -- extracted

200: disp. 112 -. extracted

200: disp.px -.. extracted

200: disp.ry -. extracted

200: disp.r10 -. extracted

200: species.do -. extracted

200: species.f1 .. extracted

200: species. $\$ 12$.. extracted

200: species. 42 -. extracted

- extracted

200: species.r -. extracted

200: species.r1 -. extracted

200: species $r 10$-. extrected

200: sy doc -.. extracted

200: ani.do $\quad$-. extracted

200: ani.f -. extracted

200: ani.f1 -. extracted

200: ani. $f 10$-. extracted

200: ani.f11 -. extracted

200: ani. $f 12 \quad$-. extracted

200: ani.f2 -. 
diskette

Diskette 2 prompted to insert the diskette labeled NRA Distributed Access 2.

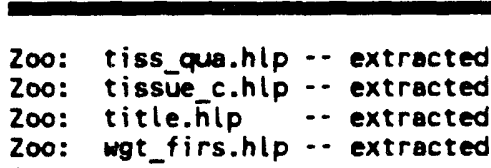

Insert WRA Distributed Access Diskette 2 in 8 :

Strike a key when ready...

Another list of files moving from diskette to hard disk will be shown on the screen. Finally, the process will terminate with the following message:

NRA Distributed Access successfully installed.

Type MRA to run NRA Distributed Access.

strike a key when ready... 
Using Paradox Runtime as supplied
To use the NRA distributed database access software with the runtime version of Paradox ${ }^{\oplus}$, simply set your DOS default to the disk drive containing the NRA Distributed Access package (assume it is $\mathrm{C}$ :), change your default directory to NRA and enter the command NRA.

C:

CD $\backslash$

CD NRA

NRA
Using your own copy of Paradox ${ }^{\oplus}$
C:

CD 1

CD NRA

PARADOX

F10

SCRIPTS

PLAY

UTILIMAIN 
Menu

Navigation

Before the Main Menu

Title Screen
The NRA Distributed Access system is completely menu driven. Menu items may be selected by moving the menu selection bar with the cursor control keys and hitting the Enter key, or by pressing the first letter of the menu choice. The menu choice which will be selected is highlighted.

The Escape key will always move you up one level in the menus. You may exit from the NRA Distributed Access application from any menu by selecting "Quit". Feel free to use the F1 key to obtain a help window at any' time.

When you start the NRA Distributed Access system, you will see three screens before you get to the Main Menu. The Title screen assures you that you are running the NRA Distributed Access system and indicates the version number. The two subsequent license screens are a necessary legal requirement.

The title screen is the first screen you will see.

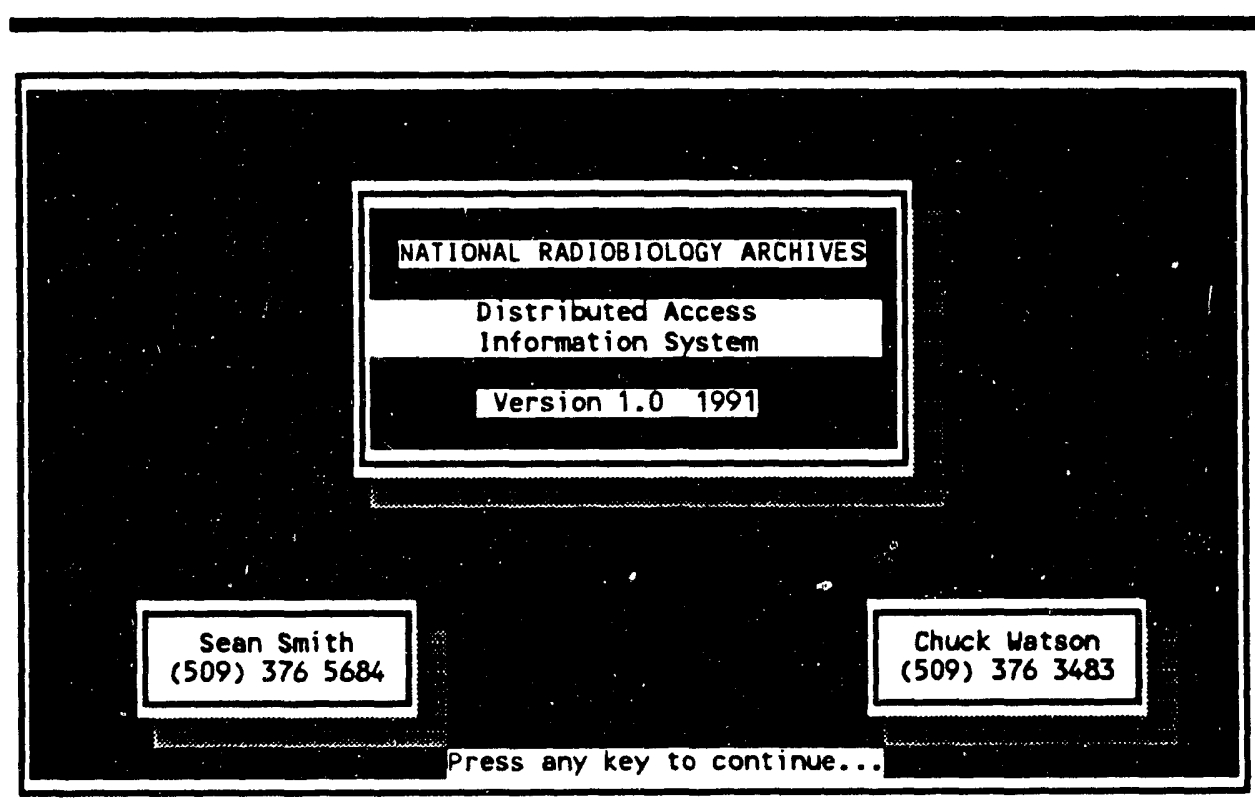


License

Agreement

Screen

Paradox ${ }^{\oplus}$

Runtime

Disclaimer
The second screen shows the Department of Energy license, agreement:

This computer sof tware has been developed under sponsorship of the Departinent of Energy (DOE). Any further distribution by any holder of this software package, its accompanying documentation, or other data therein outside of DOE offices or other DOE contractors, unless otherwise specifically provided for, is prohibited without the approval of the National Energy Software Center (NESC). Requests from outside DOE and its contractors shall be submitted to:

Director, National Energy Software Center. Argonne Mational Laboratory.

9700 South Cass Avenue.

Argonne, Illinois 60439 .

This material was prepared as an account of work sponsored by an agency of the United States Government. Neither PNL nor the U.S. Goverment, nor any of their employees, makes any warranty, express or implied, or assimes any legal liability or responsibility for the accuracy, completeness, or usefulness of any information, apparatus, product, or process disclosed, or represents that its use would not infringe privately owned rights.

Press any key to continue...

This software packege is running under Paradox Runtime (Copyright 1990 , Borland International, all rights reserved). By pressing a key to continue, you agree to:

- acknowledge that Paradox Runtime is owned by Borland International and may not be copied,

- Look to PNL, the application developer, and not Borland International, for any support strvices required by this application,

- rake no action against Borland International for any damages resulting from the use of this application, it being understood that Paradox Runtime is provided by Borland International "AS IS" and without warranties or liabilities for amy denages.

Press any key to continue... 
Menu Structure
MAIN MENU

INFORMATION

SUMMARY

HOLDINGS

BROWSE

SEARCHES

ANIMAL

ASSIGNED_ID

STUDY

T-EFFECT

T-DOSE

RETURN

MAIN

QUIT

RETURN

QUIT

INVENTORY

HCLDINGS

BROWSE

SEARCHES

ANIMAL

ASSIGNED_ID

STUDY

RETURN

MAIN

RETURN

QUIT

QUIT

BIBLIOGRAPHY

HOLDINGS

BROWSE

SEARCHES

AUTHOR

TITLE

YEAR

RETURN

MAIN

QUIT

RETURN

QUIT

DETAIL

HOLDINGS

RETURN

QUIT

HELP

PURPOSE

CURSOR KEY

FUNCTION KEY

RETURN

QUIT
Information display

Go to Summary Menu

Information display

Data display

Go to Search Menu

Select animal(s)

Select animal(s)

Select animals in study(s)

Select animals by effect(s)

Select animals by dose(s)

Go to Summary Menu

Go to Main Menu

Go to DOS

Go to Main Menu

Gn to DOS

Go to Inventory Menu

Information display

Data display

Go to Search Menu

Select animal(s)

Select animal(s)

Select animals by study(s)

Go to Inventory Menu

Go to Main Menu

Go to DOS

Go to Main Menu

Go to DOS

Go to Bibliography Menu

Information display

Data display

Go to Search Menu

Select books by author(s)

Select books by title(s)

Select books by year(s)

Go back to Bibliography Menu

Go to Main Menu

Go to DOS

Go to Main Menu

Go to DOS

Information display

Information Display

Go to Main Menu

Go to DOS

Information display

Information display

Information display

Information display

Go back to Help Menu

Go to DOS

Go to DOS 
National Radiobiology Archives

\begin{tabular}{|l|l|}
\hline \multicolumn{2}{|c|}{ MAIN MENU } \\
\hline Information & $\begin{array}{l}\text { Description of the National Radiobiology Archives. } \\
\text { Sumary }\end{array}$ \\
Access the animal related Dose-effects database. \\
Inventory & Access Specimen and Documents Inventory database. \\
Bibliography & Access the Bibl iographic citation database. \\
Detail & Description of the Detailed database tables. \\
HELP & How to use this software. \\
Quit & Exit, return to DOS. \\
\hline
\end{tabular}

Summary Menu

\begin{tabular}{|c|c|}
\hline \multicolumn{2}{|r|}{ Mational Radiobiology Archives } \\
\hline \multicolumn{2}{|r|}{ MAIN MENU } \\
\hline \multicolumn{2}{|r|}{ SUMMARY DATABASE } \\
\hline $\begin{array}{l}\text { Holdings } \\
\text { Browse } \\
\text { Searches } \\
\text { Return } \\
\text { Quit }\end{array}$ & $\begin{array}{l}\text { Read description of NRA Sumary Database holdings. } \\
\text { Brouse Dose-effects Summary Database. } \\
\text { Retrieve subset of Dose-effects Sumary Database. } \\
\text { Return to previous menu. } \\
\text { Exit, return to DOS. }\end{array}$ \\
\hline
\end{tabular}


Inventory Menu

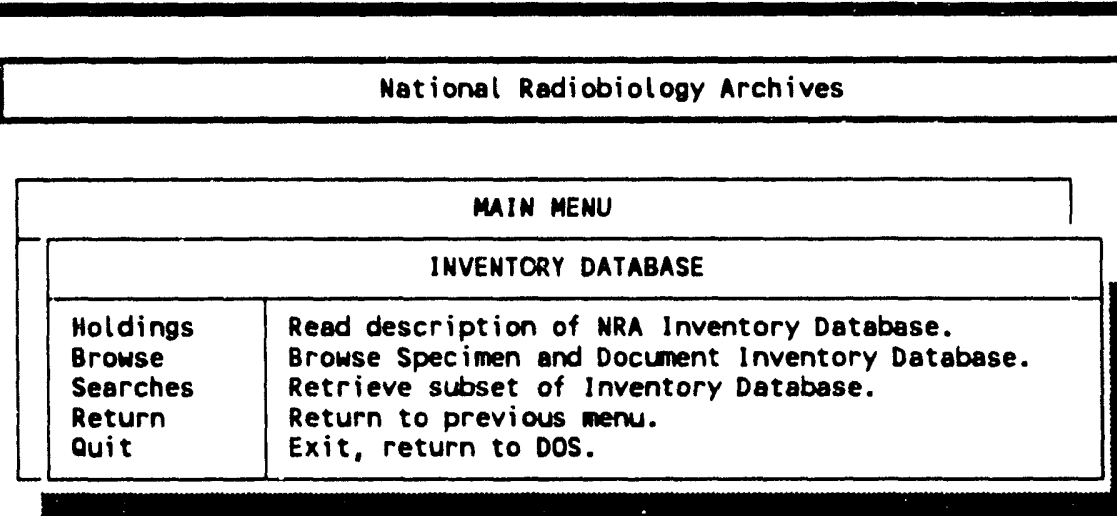

Bibliography

Menu

\begin{tabular}{|c|c|}
\hline \multicolumn{2}{|r|}{ National Radiobiology Archives } \\
\hline \multicolumn{2}{|r|}{ MAIN MENU } \\
\hline \multicolumn{2}{|r|}{ BJBLJOGRAPHY DATABASE } \\
\hline $\begin{array}{l}\text { Holdings } \\
\text { Brouse } \\
\text { Searches } \\
\text { Return } \\
\text { Quit }\end{array}$ & $\begin{array}{l}\text { Read description of NRA Bibliography Database. } \\
\text { Browse bibliographic citations. } \\
\text { Retrieve subset of bibl iography database. } \\
\text { Return to previous menu. } \\
\text { Exit, return to Dos. }\end{array}$ \\
\hline
\end{tabular}


Summary

Database Search Menu

Search by Animal Number
National Radiobiology Archives

\begin{tabular}{|c|c|}
\hline \multicolumn{2}{|r|}{ MAIN MENU } \\
\hline \multicolumn{2}{|r|}{ SLMMARY DATABASE } \\
\hline \multicolumn{2}{|r|}{ SEARCH THE SUMMARY DATABASE } \\
\hline $\begin{array}{l}\text { Animal } \\
\text { Assigned ID } \\
\text { T-effect } \\
\text { T-dose } \\
\text { Study } \\
\text { Return } \\
\text { Main } \\
\text { Quit }\end{array}$ & $\begin{array}{l}\text { Retrieve Animals by animal number(s). } \\
\text { Retrieve Animals by assigned ID(s). } \\
\text { Retrieve Animals by tissue effect category(ies). } \\
\text { Retrieve Animals by tissue dose(s). } \\
\text { Retrieve Animals by study } 10 \text { code(s). } \\
\text { Return to previous monu. } \\
\text { Return to Main Menu. } \\
\text { Exit, return to DOS. }\end{array}$ \\
\hline
\end{tabular}

National Radiobiology Archives

\section{MAIN MENU}

SLMMARY SEARCH BY ANIMAL WUMBER ANIMAL NUMBER:

Type in search string (wildcard $\ldots$...) [F1]-view list of choices [F2], [ENTER]-execute search

Assigned ID | Retrieve Animals by assigned ID(s).

$T$-effect Retrieve Animals by tissue effect category(ies).

$T$-dose $\quad$ Retrieve Animals by tissue dose(s).

Stuch $\quad$ Retrieve Animals by study ID code(s).

Return $\quad$ Return to previous menu.

Main $\quad$ Return to Main Meru.

Quit Exit, return to DOS. 
F1 option shows list of animals
F2-Execute search for items selected ENTER-Select or un-select item

Esc-Return to menu CURSOR KEYS, PGUP, PCDN, HONE, END-Scroll list

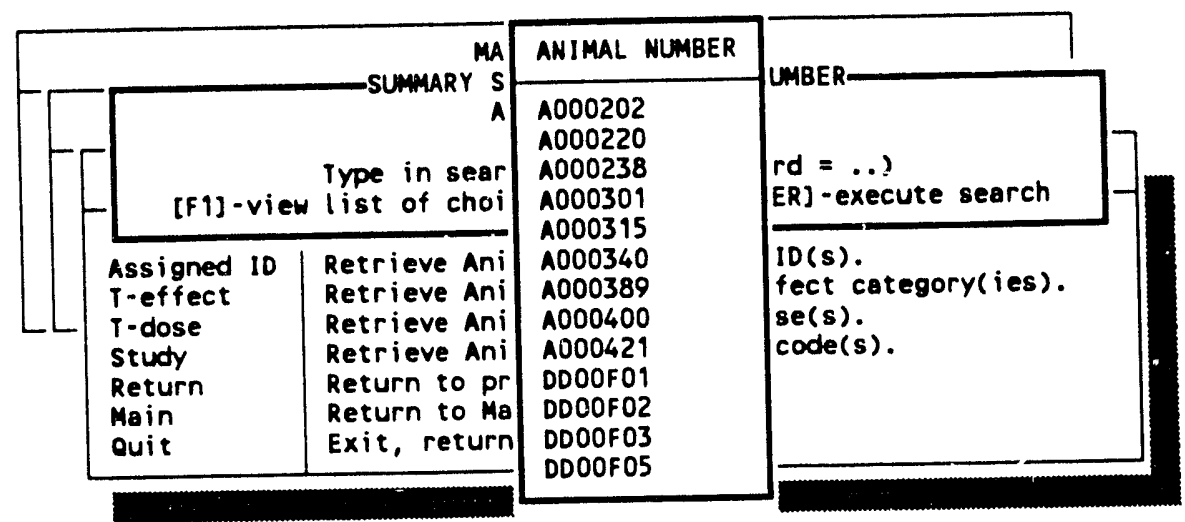


Printer

Assumptions

NRA Philosophy on Reports
The NRA Distributed Access package is designed to help people understand the scope of the National Radiobiology Archives Information Systems. It has a limited capacity to create reports. You may direct these reports to a DCS file and use them as any other ASCII file. You may also direct these reports to your printer. The printed reports will be directed to LPT1. They do not require graphics or special fonts; they are designed for a generic printer.

Reports reflecting the browse screens are part of the NRA Distributed Access system. However, summary reports, tabulating information such as number of animals with a specific neoplasni are not provided. Summary reporting is basically an ad hoc activity requiring Paradox usage and familiarity.

The printed reports contain more information than is shown on the screen. The reports are designed to display as much of the database contents as possible, therefore, they do not mimic the screen. The browse screens are designed to provide a reasonable view of the records to aid in the selection of subsets for analysis. The reports are intended to be part of the analysis.

Printed reports of the clinical description of an animal or of the menu help files may also be obtained. 
Summary

Database

Browse - Print option, F6
The F6 (PRINT) key is functional on browse screens. If you were browsing the Summary database, and were viewing animal DD00F01, you would see the following:

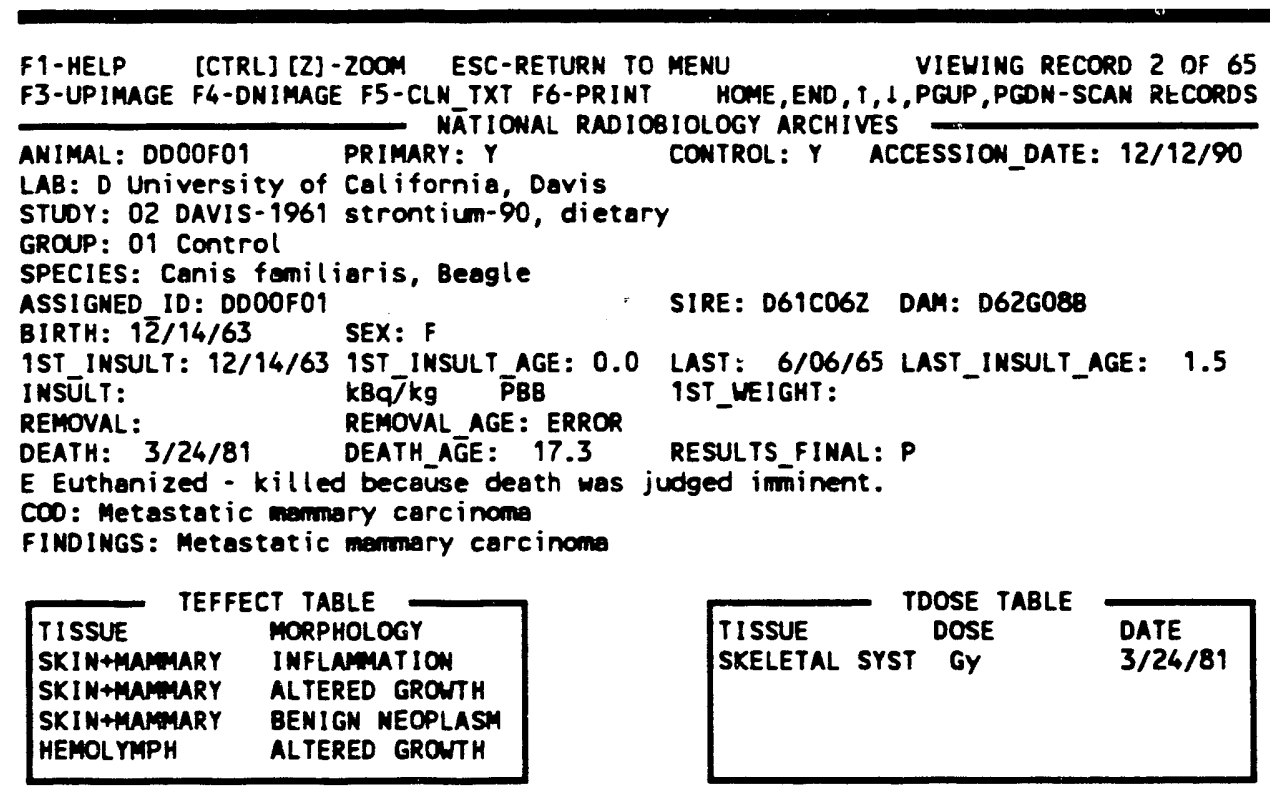

At that time, if you press F6, the top of the screen would display the print option menu:

FILE PRINTER EXIT

Send Report to file...

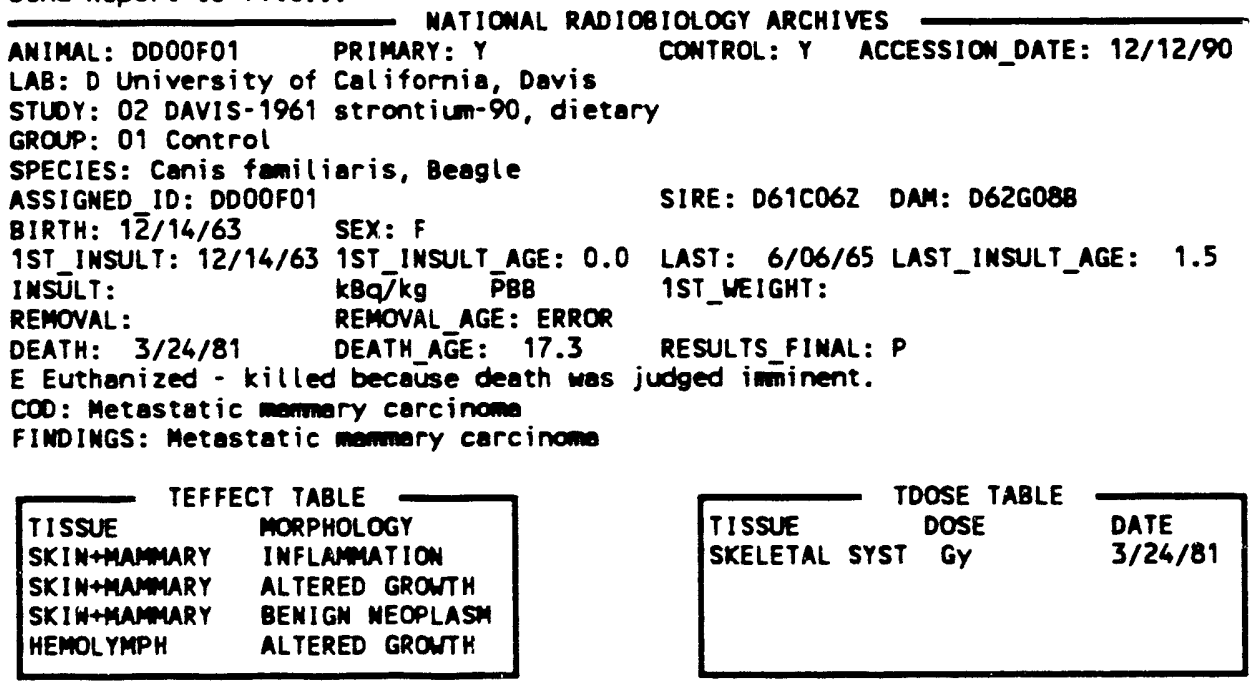


Selection of the FILE option prompts you to enter the name of the output file. Enter the name (maximum of 8 characters) without file type suffix. The software will append ".RPT" automatically.

Enter an 8 character file name:test

File with . RPT will be placed in C: INRAI

ANIMAL: DDOOFOI NATIONAL RADIOBIOLOGY ARCHIVES

ANIMAL: DDOOF01 PRIMARY: Y
LAB: D University of California, Davis

STUOY: 02 DAVIS-1961 strontium-90, dietary

GROUP: 01 Control

SPECIES: Canis familiaris, Beagle

ASSIGMED ID: DDOOFOI

BIRTH: $1 \overline{2} / 14 / 63$ SEX: F

1ST INSULT: 12/14/63 1ST INSULT AGE: 0.0 LAST: 6/06/65 LAST INSULT AGE: 1.5

IMSULT:

IST INSULT,ACE

REMOVAL: $\quad$ REMOVAL AGE: ERROR

DEATH: 3/24/81 DEATH_AGE: 17.3

CONTROL: $Y$ ACCESSION DATE: $12 / 12 / 90$

COO:

FINOINGS: Metastatic mamary carcinoma

\begin{tabular}{ll}
\hline TISSUE & TEFFECT TABLE \\
MORPHOLOGY \\
SKIN+MAMMARY & INFLAMMATION \\
SKIN+MAMMARY & ALTERED GRONTH \\
SKIN+MAMMARY & BENIGN NEOPLASH \\
HEMOLYMPH & ALTERED GROWTH
\end{tabular}

\begin{tabular}{|lll|}
\hline TISSUE & DOSE & DATE \\
SKELETAL SYST & GY & $3 / 24 / 81$ \\
& & \\
& & \\
& &
\end{tabular}

After you enter the file name, in this case "test", the following display will indicate that the file is being created.

Sending report to file: C:INRAltest.RPT

ANIMAL: DDOOFOI PRIMARY: $Y$

NATIONAL RADIOBIOLOGY ARCHIVES

LAB: D University of California, Davis

CONTROL: $Y$ ACCESSION_DATE: $12 / 12 / 90$

STLOY: 02 DAVIS-1961 strontium-90, dietary

GROUP: 01 Control

SPECIES: Canis familiaris, Beagle

ASSIGNED 10: D000F01

BIRTH: $1 \overline{2} / 14 / 63$

SEX: $F$

1ST_INSULT: 12/14/63 1ST_INSULT_AGE: 0.0 LAST: 6/06/65 LAST_INSULT_AGE: 1.5

INSÜLT:

KBajkg PBB

REMOVAL: REMOVAL AGE: ERROR

DEATH: 3/24/81 DEATH_AGEE: 17.3

Euthanized - killed because death was judged imminent.

Metastatic mamary carcinoma

FINDINGS: Metastatic mannary carcinoma

\begin{tabular}{|ll|}
\hline TISSUE TEFFECT TABLE \\
SKIN+WMWIARY & MORPHOLOGY \\
SKINFLAMUTION \\
SKIN+WAMARY & ALTERED GRONTH \\
HEMOLYMPH & BENIGN MEOPLASM \\
\hline
\end{tabular}

\begin{tabular}{|c|c|c|}
\hline $\begin{array}{l}\text { TISSUE } \\
\text { SKELETAL }\end{array}$ & SYST GY & $\begin{array}{l}\text { DATE } \\
3 / 24 / 81\end{array}$ \\
\hline
\end{tabular}


Output to Printer
If you choose to send the output directly to the printer, the following message will appear:
Sending report to the printer

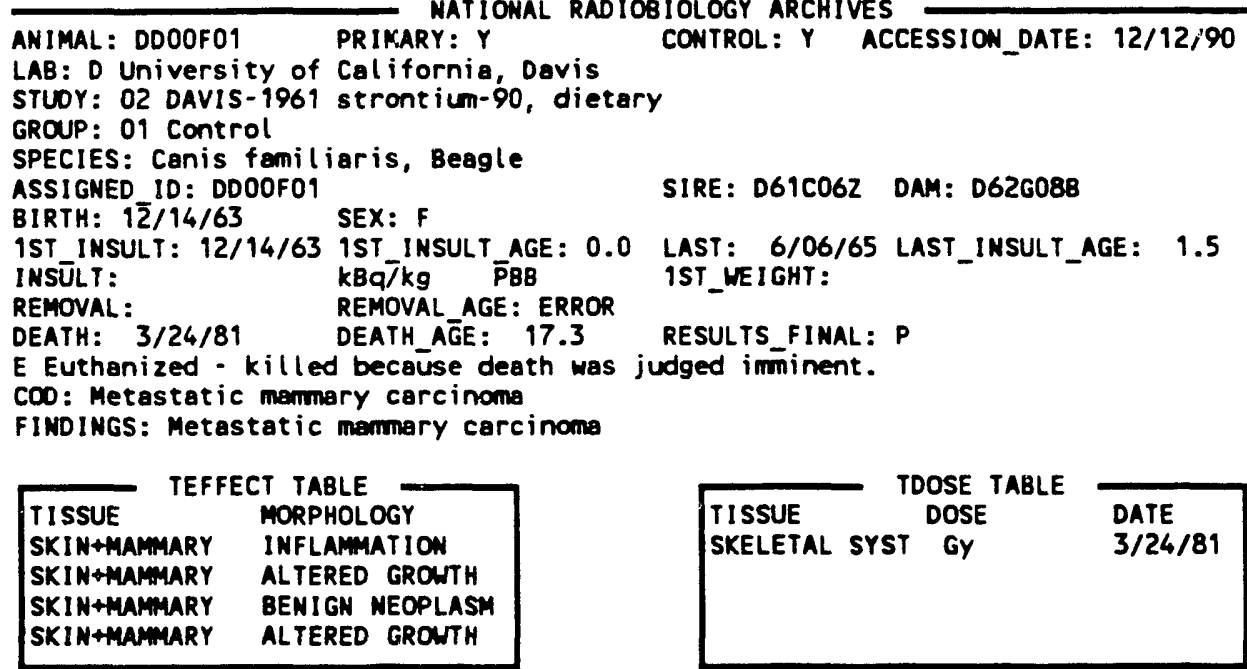


Animal

Summary

Report example
The report generated by the steps shown above is:

NATIONAL RADIOBIOLOGY ARCHIVES

$10 / 07 / 91$

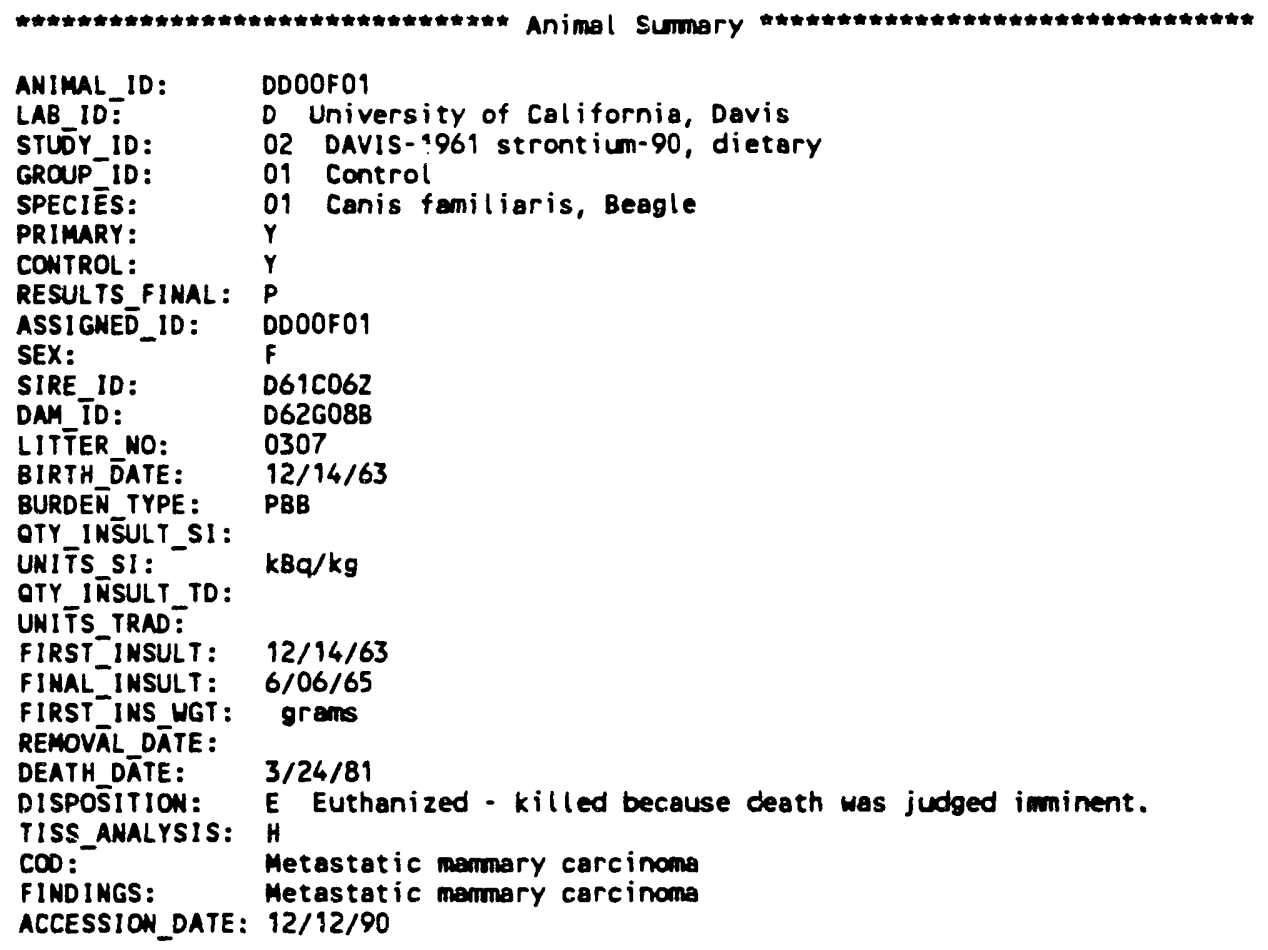

NATIONAL RADIOBIOLOGY ARCHIVES NATIONAL RADIOBIOLOGY ARCHIVES

\begin{tabular}{|c|c|c|c|c|}
\hline TOPO_COOE & TOPOGRAPHY & MORPH_COOE & MORPHOLOGY & $D X$ \\
\hline $\begin{array}{l}T 560009 \\
T 701109 \\
T 702009 \\
T 702009 \\
T 702009 \\
T 900009 \\
T 900009\end{array}$ & $\begin{array}{l}\text { LIVER } \\
\text { KIDNEY } \\
\text { FEMALE REPRO } \\
\text { FEMALE REPRO } \\
\text { FEMALE REPRO } \\
\text { ENDOCRINE } \\
\text { ENDOCR INE }\end{array}$ & $\begin{array}{l}M 800000 \\
M 400009 \\
M 400009 \\
M 700009 \\
M 800000 \\
M 500009 \\
M 800000\end{array}$ & $\begin{array}{l}\text { BENIGN NEOPLASM } \\
\text { INFLAMMATION } \\
\text { INFLAMMATION } \\
\text { ALTERED GRONTH } \\
\text { BENIGN NEOPLASM } \\
\text { DEGENERATION } \\
\text { BENIGN NEOPLASM }\end{array}$ & $\begin{array}{l}\cdots \\
C \\
H \\
B \\
B \\
H \\
H \\
H\end{array}$ \\
\hline
\end{tabular}




$\begin{array}{llll}\text { TX00009 } & \text { CNS + EYES } & \text { M500009 } & \text { DEGENERATION } H \\ \text { TX00009 } & \text { CNS + EYES } & \text { M800000 } & \text { BENIGN NEOPLASM H }\end{array}$

TISSUE CATEGORY: SKELETAL SYS

DOSE_UN̄ITS: GY TYPE_LAST_NORMAL: DOSE_LAST_NORMAL:

LAST_NORMAL: TYPE_LAST_NORMAL: DOSE_LAST_NORMAL:

DATE_CLIN_DX: TYPE_CLIN_DX : DOSE_CLIN_DX :

DATE-TISS_DX: $3 / 24 / 81$ TYPE_TISS_DX : H DOSE_TISS_DX :

DOSE_ERR_TISS_DX :

NATIONAL RADIOBIOLOGY ARCHIVES

Report shows more than screen

Inventory Browse Screen example
Note that there are several fields shown on the report which are not shown on the screen. This is due to space limitations on the screen. The reports will show the full database record for the animal. The report is divided into three sections, the ANIM IAL TABLE is printed at the top, the TISSUE EFFECTS TABLE is in the middle, and the TISSUE DOSE TABLE is shown at the bottom.

The following screen is an example browse of the inventory database.

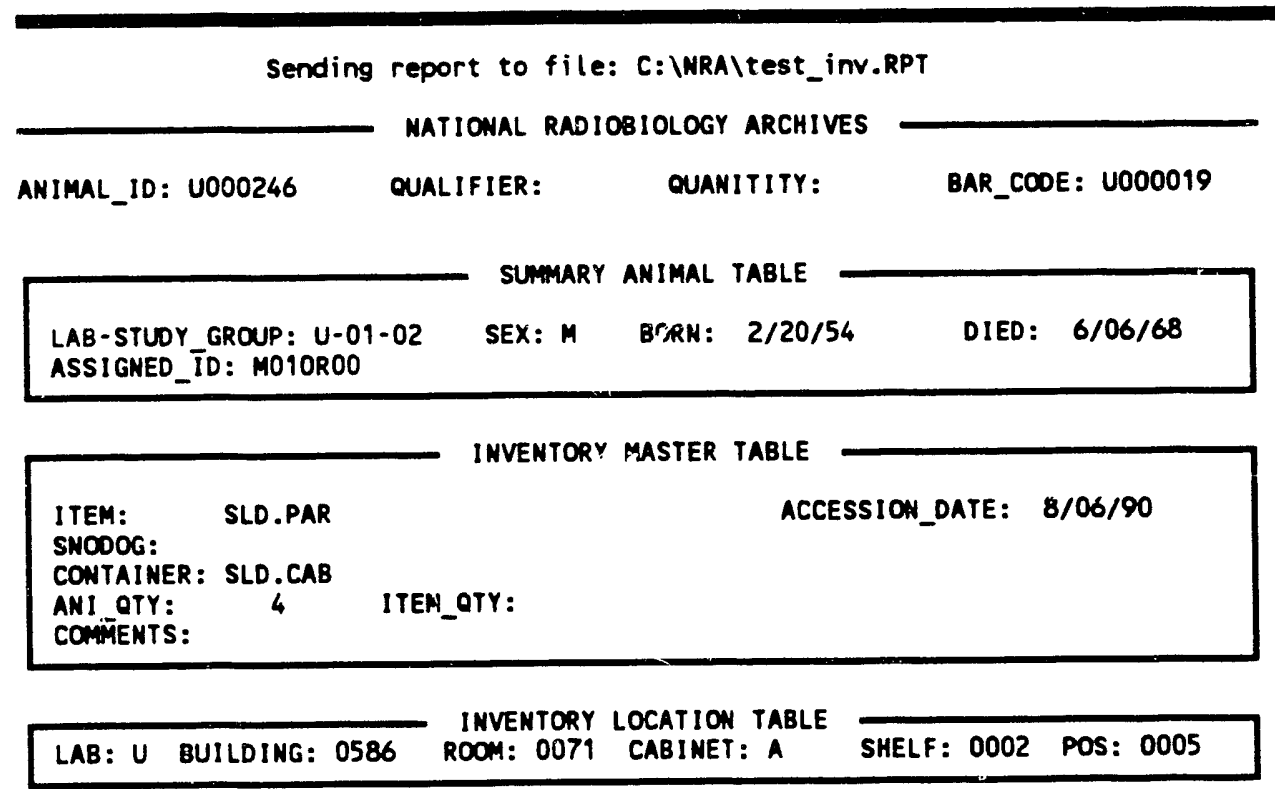


Inventory

Report example
The report produced from the screen above is:

NATIONAL RADIOBIOLOGY ARCHIVES

10/07/91

INVENTORY DATABASE REPORT

Page: 1

HAH

ANIMAL_ID: U000246 QUALIFIER: OUANTITY: BAR_CODE: U000019

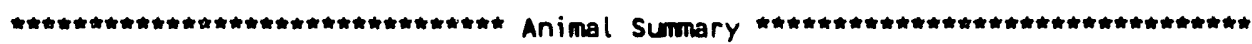

ANIMAL ID: $\quad$ U000246

LAB ID: $\quad U$

STUŌY_ID: $\quad 02$

GROUP ID: 01

SPECIES: $\quad 01$

PRIMARY:

CONTROL:

RESULTS FIMAL:

ASSIGNED__ID: MOIOROO

SEX: - $M$

SIRE ID: $\quad$ U009910

ONM TO: U009912

LITTER_NO: $\quad 0000$

BIRTH_DATE: $\quad 2 / 20 / 54$

BURDEN TYPE:

OTY_INSULT_SI:

UNITSSSI:

OTY_INSULT_TD: 0

UNITS TRAD:

FIRST_INSULT: $\quad 7 / 27 / 55$

FINAL_INSULT: $7 / 27 / 55$

FIRST INS WGT: 10900 grans

REMOVĀL_DĀTE:

DEATH DATE: $\quad 6 / 06 / 68$

DISPOSITION:

TISS AMALYSIS:

COO:- not available

FINDINGS: NEPHRITIS

ACCESSION_DATE: 11/09/90

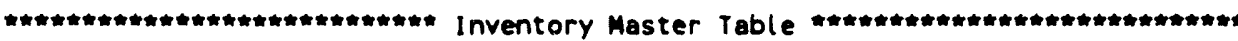

ITEM: SLD.PAR ACCFSSION_DATE: 8/06/90

FORE_COOE :

SNOOOOG:

CONTAINER: SLD.CAB

AKI OTY:

ITEM QTY:

COMMENTS:

MATIONAL RADIOBIOLOGY ARCHIVES NATIONAL RADIOBIOLOGY ARCHIVES

$10 / 07 / 91$

INVENTORY DATABASE REPORT

Page: 2

Inventory Location Table

LAB : $\quad U$

DATE: $\quad 8 / 06 / 90$

STATUS: 1

BUILDING: 0586

ROOH: 0071

CABINET: A

SHELF: 0002

POS: 0005 
Bibliography Browse Screen example
An example browse screen from the bibliography database is shown below:

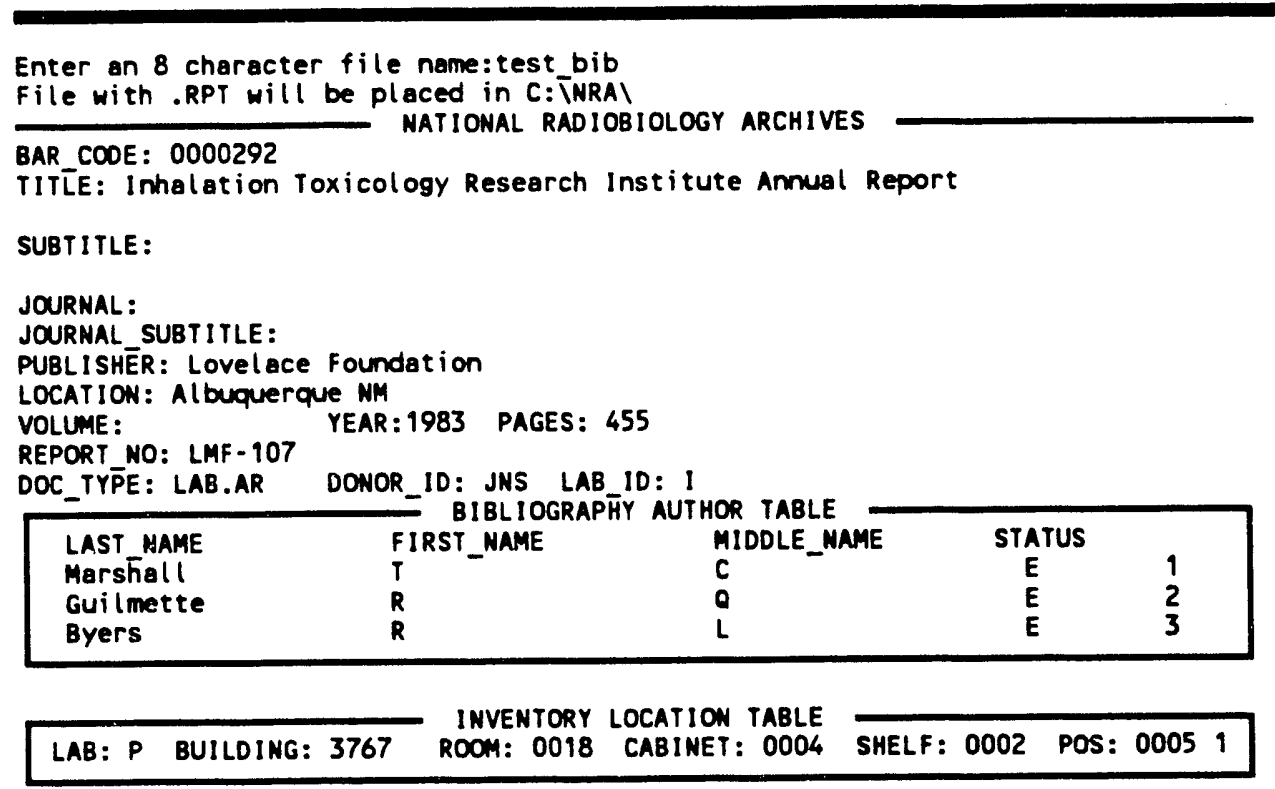


Bibliography Report example
The report produced from the example above contains more information than will fit on the screen.

NATIONAL RADIOBIOLOGY ARCHIVES

10/07/91

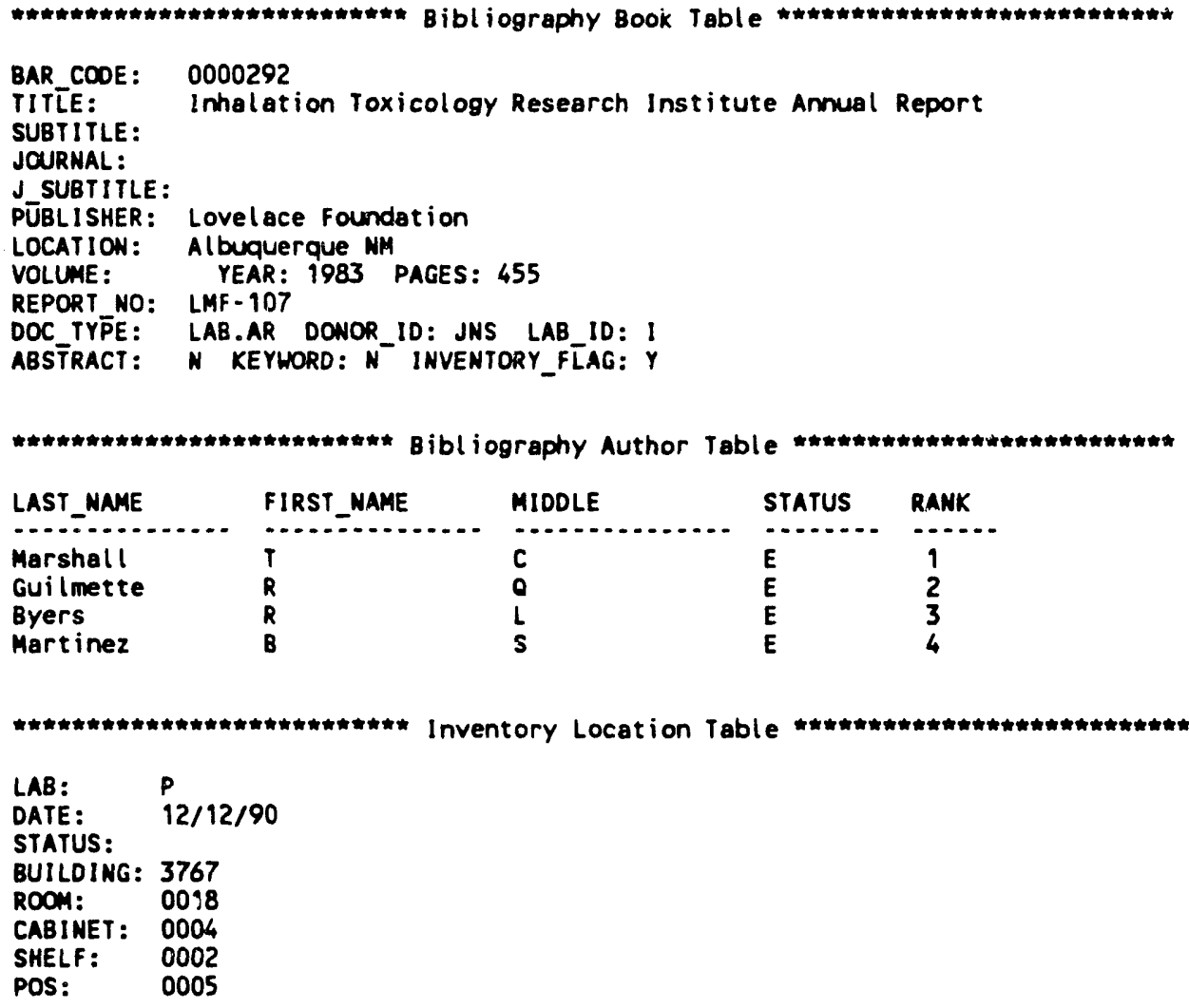


Types of Information Available

Active disk storage

Summary Database
There are four general categories of information available in the NRA Information Systems. The summary and detailed databases are related specifically to animals used in dose-effects studies. The inventory database is related to physical materials in the NRA Document and Specimen Archives. The bibliography database provides access to published materials in Radiobiology. The purpose of this section is to describe the scope and magnitude of the full database maintained at PNL. The next section describes the distributed subset.

The NRA Information System consists of many relational database tables, only a few are included in the subset distributed with the NRA Distributed Access Package. The following description of the full information systems structure is provided so that you will be aware of the scope of information available on request.

The disk storage in use at the NRA in October, 1991 is summarized in the following table:

\begin{tabular}{|r|c|c|c|c|}
\hline Category: & Paradox & Summary & Inventory & Biblio \\
\hline Megabytes: & 2.0 & 11 & 1.5 & .9 \\
\hline Tables: & $\mathrm{n} / \mathrm{a}$ & 8 & 5 & 2 \\
\hline
\end{tabular}

There are 8 tables in the Summary Database. These tables and their associated validation tables and indexes require about 11 megabyies of disk storage.

$L a b$

The Lab table contains descriptions of the donating laboratories, including the name and address of the PI.

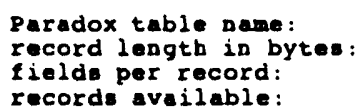

The Lab table is complete, and its contents have been reviewed by the PI's.

\section{Study}

The Study table contains descriptions of the studies. It describes the completion status, type and frequency of insult, chemical form and age of the animals. It includes a short narrative abstract. 
The Study table is complete for the 5 beagle laboratories, and its contents have been reviewed by the PI's. Records for CSU and ORNL are under review.

Group

The Group table contains descriptions of the groups within each study. It describes the completion status, number of animals, and quantity of insult.

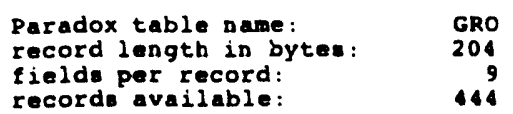

The Group table is complete for the 5 beagle laboratories, and its contents have been reviewed by the PI's. Records for CSU and ORNL are under review.

\section{Animal}

The Animal table contains descriptions of the individual animals. It contains demographic information (birth, death, parents, etc.), insult information, and a brief description of the cause of death or findings.
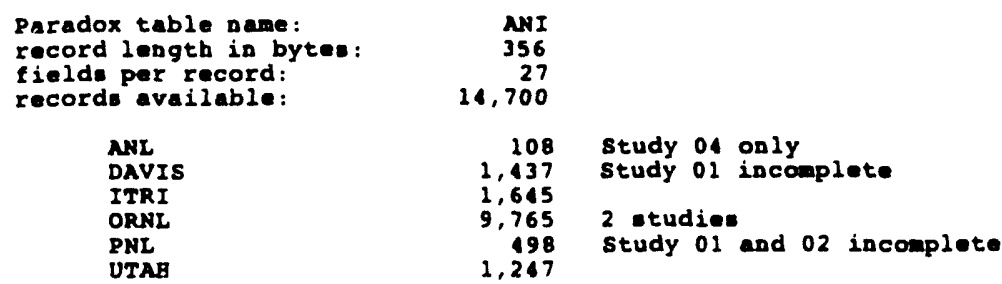

The Animal table is growing as the donating laboratories contribute additional information.

\section{Tissue Dose}

The Tissue Dose table contains descriptions of the dose delivered to various tissues. It has fields for 3 doses: on the date the tissue was last observed to be normal, on the date of diagnosis, and at death. At present, only the dose at death is available.

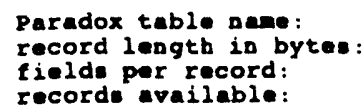

The Tissue Dose table will grow as the donating laboratories contribute additional information.

\section{Function}

The Function table contains a description of a function used to compute dose to 
a tissue category at a given time.

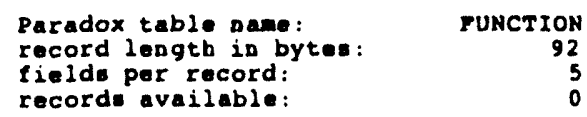

The Function table is empty pending donation of additional information.

\section{Tissue Effect}

The Tissue Effect table contains summary descriptions of the effect observed in various tissues.

$\begin{array}{lr}\text { Paradox table name: } & \text { TEFFECT } \\ \text { record length in byteo: } & 21 \\ \text { fields per record: } & 3 \\ \text { recorde available: } & 11,092 \\ & \\ \text { ANL } & 820 \\ \text { DAVIS } & 9,151 \\ \text { ORNL } & 11,813 \\ \text { UTAR } & 19,308\end{array}$

The rissue Effect table will grow as the donating laboratories contribute additional information.

\section{Control}

The Control table relates each control animal to the study or studies for which it is a control.
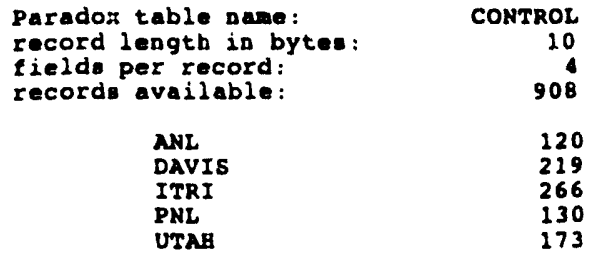

The Control table is growing as the donating laboratories contribute additional information.

The Inventory database has 5 tables which occupy about 1.5 megabytes of disk space:

\section{Master}

The Master table contains descriptions of each container in the specimen archives and each document in the records archives. This is the definition of the bar code labels.

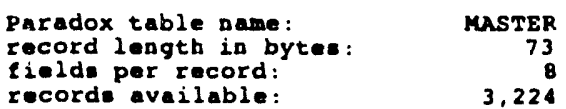




\section{Location}

The Location table indic ates the physical location of each item listed in the Master table. An additional record is added to the location table when an inventory item is moved or loaned.

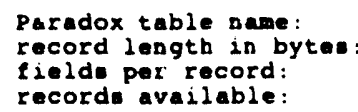

LOCATION

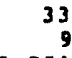

3,251

Detail

The Detail table relates individual animals to inventory bar codes.

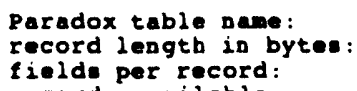

\section{Patron}

The Patron table describes users of the Document of Specimen Archives.

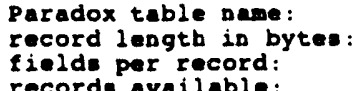

\section{Loan}

The Loan table associates bar codes in the Master table with a person in the Patron table when materials are on loan.

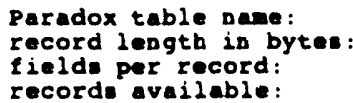

The Bibliography database consists of 4 tables, only 2 are in use. At this early stage in its development, the bibliography database requires less than 1 megabyte of disk space.

\section{Book}

The Book table holus general bibliographic information for each item in the documents archives. The books are related to the physical location in the inventory database by the bar code label. 
Paradox table name:

record length in bytes:

fielde per record:

recorde available:

Author

The Author table contains names of authors.

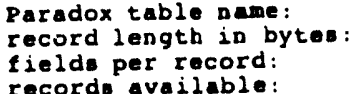

Paradox table pame:

record length in bytes:

fields per record:

record avajlable:

AUTHOR

Key Word

The Key Word table is not implemented.

\section{Abstract}

The Abstract table is not implemented.

Detailed

Database Tables
The detailed tables are laboratory specific topical files translated to the Paradox ${ }^{\oplus}$ database management system. The NRA provides documentation of the translation but does not attampt to convert information to standardized formats.

For example, each life-span study of beagles produced a computer file of serial body weights. The NRA is collecting these files, translating them to the Paradox databuse management system, and documenting their structure. The NRA is not attempting to merge the weight data from the donating laboratories. Thus, there is no standardization of weight units (grams, kilograms, etc.), date format (mmddyy or yymmdd, etc.) or format of the data value (integer, real, etc.). Users of the detailed databases are expected to normalize the data for their specific purpose. 
Selection of the Introductory subset

Disk Storage Requirements
A representative subset of the NRA Information Systems database was selected for inclusion in the Distributed Access package. A few typical control animals from each donating laboratory were chosen to make a total group of 100 animals. Dosimetry and effects records associated with these 100 animals were also selected. Similarly, 100 representative bibliographic citations were inciuded. Finally, the animals and books were matched with the inventory database tc extract asscciated records. The composition of this introductory subset is discussed in detail below.

The NRA Distributed Access package, configured with the introductory subset, requires 3.5 megabytes of disk storage. The disk space required in kilobytes is shown in this tree diagram, where the mandatory access software is shaced.

NRA Directory Tree

Storage used by Distributed Access Package

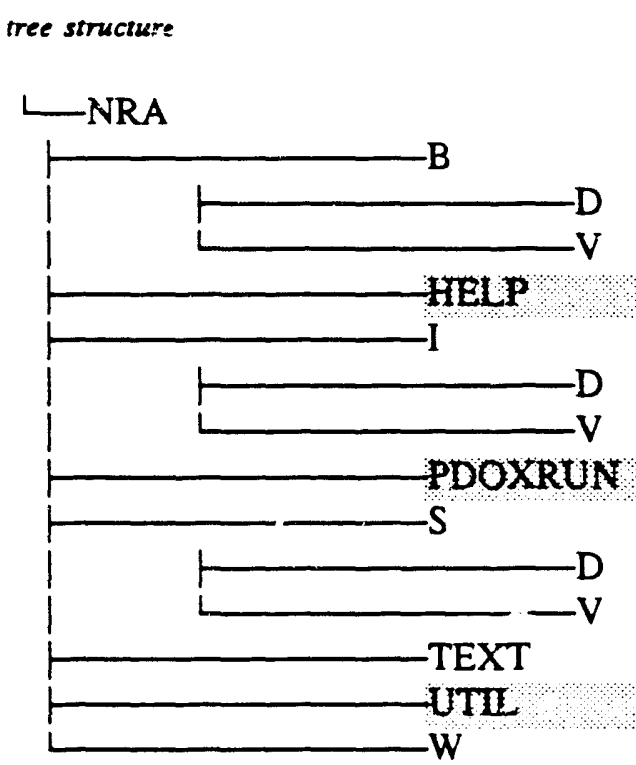

$\begin{array}{lr}\text { function } & \text { kilobytes } \\ \text { root } & 0 \\ \text { bibliography node } & 0 \\ \text { data tables } & 240 \\ \text { validation tables } & 15 \\ \text { text files } & 55 \\ \text { inventory node } & 0 \\ \text { data tables } & 89 \\ \text { validation tables } & 22 \\ \text { DBMS software } & 1.880 \\ \text { summary node } & 0 \\ \text { data tables } & 373 \\ \text { validation tables } & 27 \\ \text { clinical files } & 15 \\ \text { application software } & \text { a } \\ \text { work files } & 915 \\ \end{array}$

Space required for Access Sotware

2,450

Space required for Distributed Subset

Space required for NRA Distributed Access Package

Summary Database
There are 8 tables in the Summary Database. While these tables and their assuciateu valiuation tables and indexes currently occupy ahout 11 megabytes of disk storage at the NRA, the introductory subset is less than $\mathbf{5 0 0}$ kilobytes. 
$L a b$

The distributed subset contains the complete Lab table. There are 7 rows. A representative row is shown below:

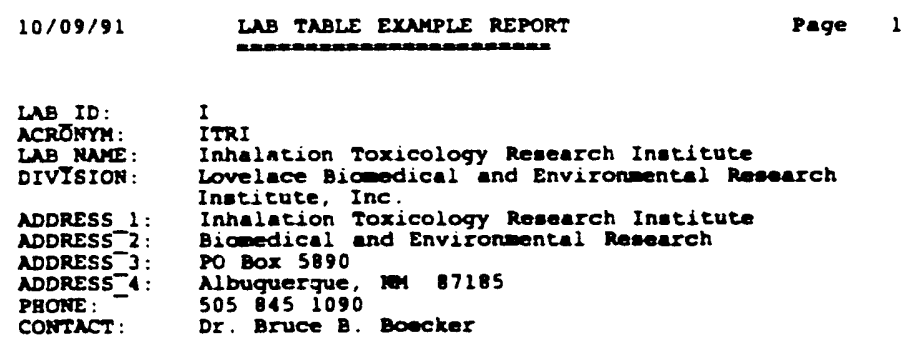

Study

The distributed subset contains the complete Study table. A representative report showing two of the 62 study records is shown below. It describes the complet:on status, type and frequency of insult, chemical form and age of the animals. It includes a short narrative abstract.

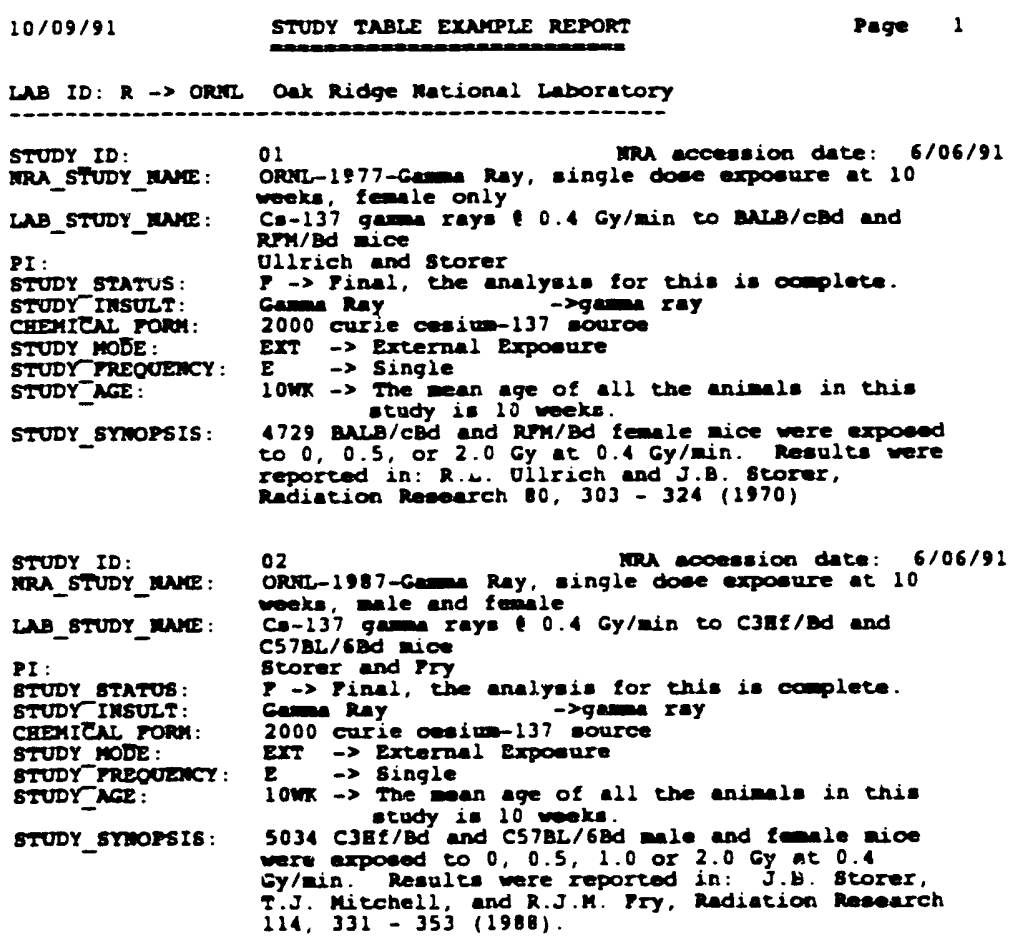


Group

The distributed subset contains the complete Group table. A representative example of one of the $\mathbf{4 4 4}$ group records is shown below. It contains descriptions of the groups within each study. It describes the completion status, number of animals, and quantity of insult.

$20 / 09 / 91$

GROUP TABLE EXUMPLE REPORT

Page 1

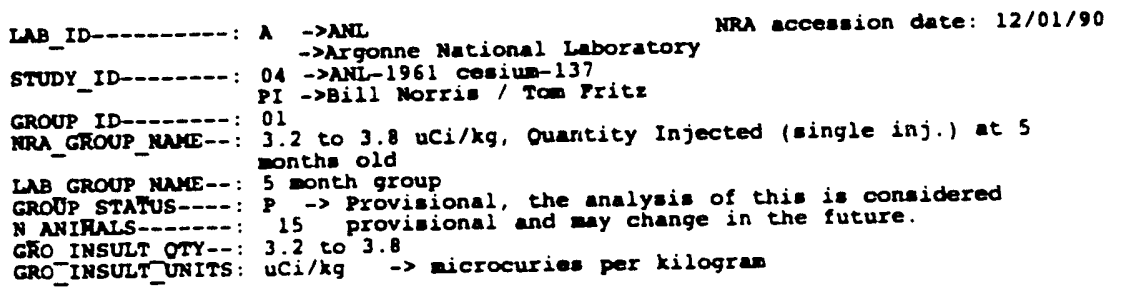

\section{Animal}

The introductory subset distributed with the NRA Distributed Access package contains 100 records from the Animal table. These are descriptions of the individual animals which contain demographic information (birth, death, parents, etc.), insult information, and a brief description of the cause of death or findings.

The 100 records were selected from the control animal population at each donating laboratory.

$\begin{array}{lc}\text { Laboratory } & \text { Controls } \\ \text { ANL } & 9 \\ \text { DAVIS } & 16 \\ \text { ITRI } & 11 \\ \text { ORNL } & 35 \\ \text { PNL } & 13 \\ \text { UTAH } & 16\end{array}$

A representative record, for Davis dog D00F01, is shown below.

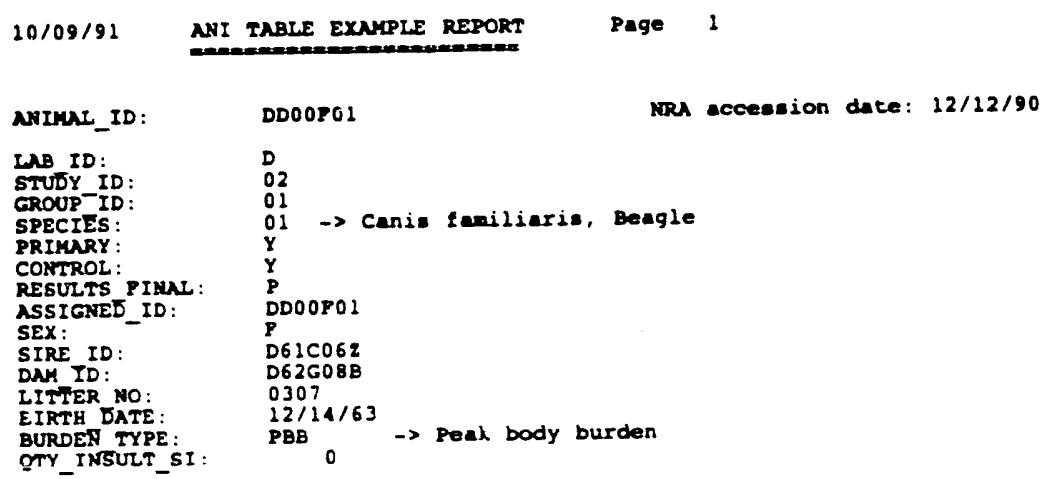


INSULT UNITS SI: $\mathrm{kBg} / \mathrm{kg} \rightarrow \mathrm{kilobecquerel/kilogras}$

OTY INSULT TRADITIONAL:

INSOLT UTITS TRADITIONAS.

PINST_IN IULT: $\quad 12 / 14 / 63$

FTT PIRS: INSULT: 9006 gran

REMOVAL IIXTE:

DEATH DXT: :

DISPOSITION

TISS OUAIITY :

CAUSE OF DEATH

\section{Tissue Effect}

The introductory subset contains 699 Tissue Effect records. These summarize observations in major tissue categories for each animal. A few records for Davis dog D00F01 are shown below.

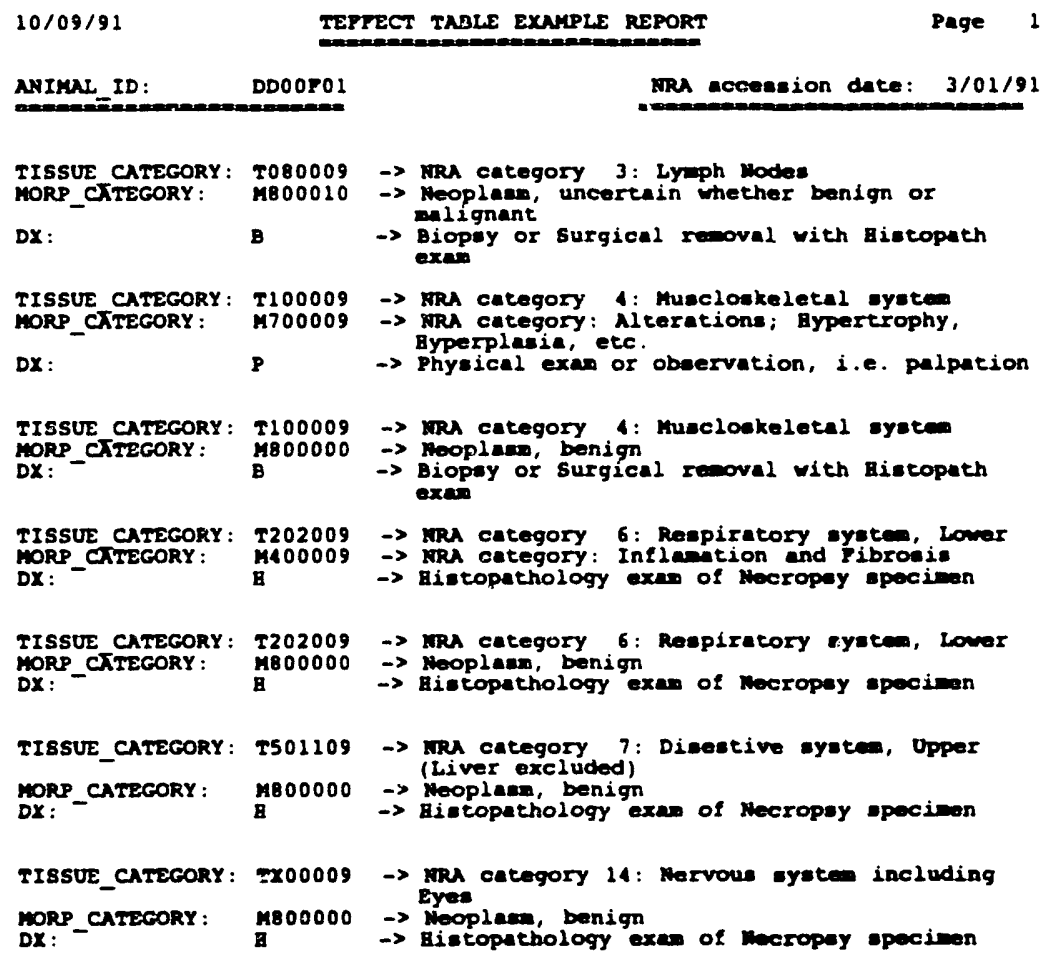

Tissue Dose

The introductory subset contains one Tissue Dose record per animal. Since these descriptions of the dose delivered to various tissues are intended for exposed animals, artificial records indicating zero dose to the whole body were created for use in the subset. In the full NRA Information System, records are stored in the Tissue Dose table only for exposed animals with well characterized dosimetry.

\section{Function}


The Function table will not be distributed until dose function information is available.

\section{Control}

The introductory subset has a Control table containing 109 records. Since all animals in the subset are controls, there is one record for each. In addition, the $9 \mathrm{ANL}$ animals served as controls for more than one study, therefore there is an additional record associating each with study " $00^{\text {" }}$ as well as study " 04 ".

Inventory Database

The Inventory database has 5 tables which occupy about 1.5 megabytes of disk space in the NRA Information System. The introductory subset contains a representative subset which only requires about 100 kilobytes of storage space.

\section{Master}

The Master table in the introductory subset contains 180 records. These describe each container in the spesimen archives and each document in the records archives. This is the definition of the bar code labels.

The records selected for the subset are directly related to the Animal and Book tables. The NRA Inventory database was joined with the 100 animal subset to identify 80 inventory Master records. In addition 100 inventory Master records related to the 100 bibliography Book records were selected. A few representative records are shown below. The example includes bibliography as well as tissue specimen inventory master records.

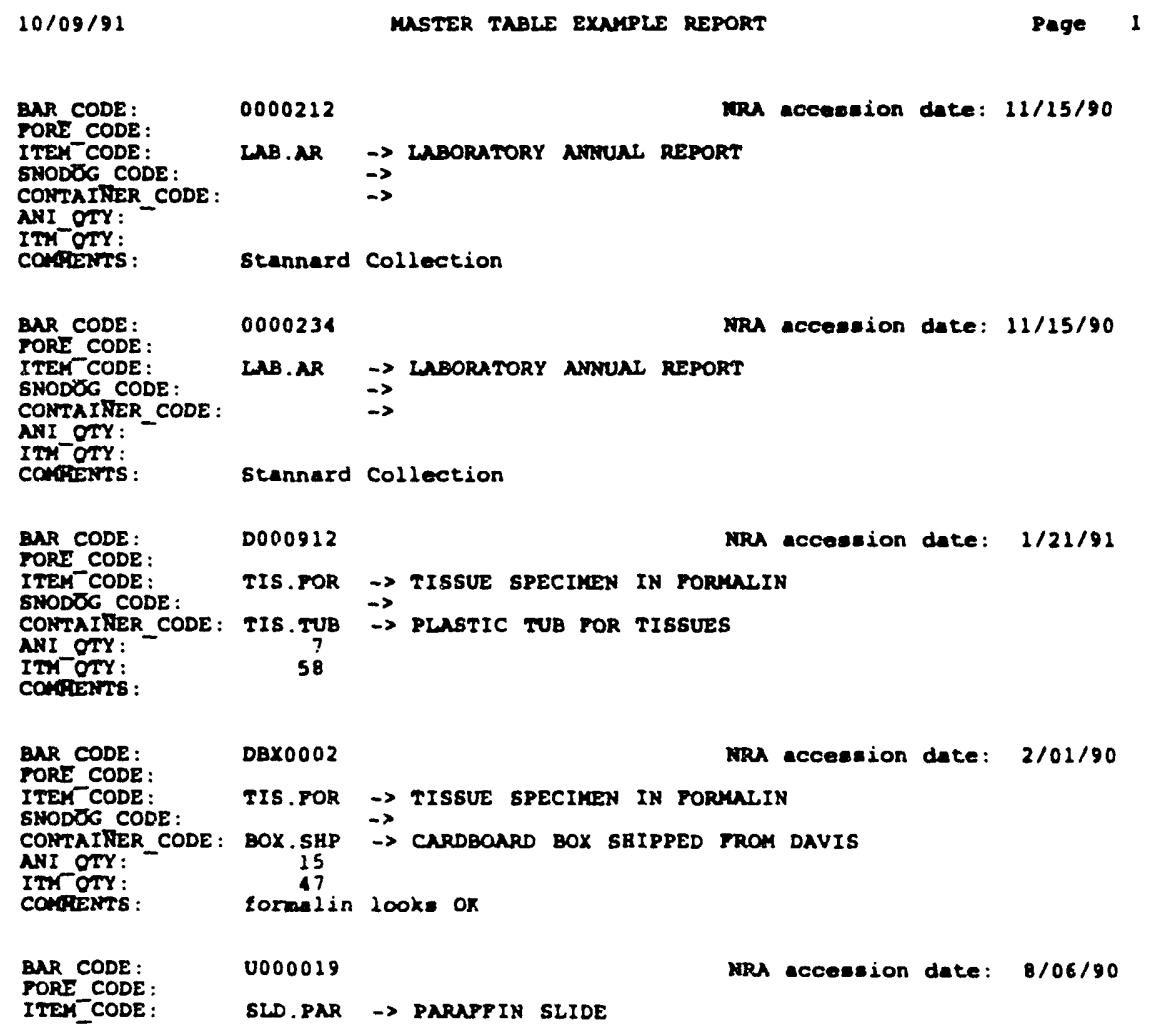

MRA accession date: $8 / 06 / 90$ 
SNODOG CODE

CONTAINER_CODE: SLD.CAB $\rightarrow$ SLIDE CABINET

ANI_OTY

conpents :

BNR CODE :

FORE CODE

ITEM CODE:

SNODOO CODE :

CONTAINER

ITH OTY

congens:

BAR CODE :

FORE CODE

SNODOC CODE :

CONTAINER CODE:

ANI_OTY

ITMOTY:
U000622

CLN.REC $\rightarrow$ CLINICAL RECOROS

$\rightarrow \rightarrow$ PILE CABINET

32

0001440

BLK.PAR $\rightarrow$ PARATTIN BLOCK

BLK. CAB 2 -> PARAFTIN BLOCK CABIKET

SOUTH OP DOOR
TRA accension date: $9 / 12 / 90$

MRA accosaion date: $11 / 08 / 90$

\section{Location}

The introductory subset contains 180 Location records associated with the 180 inventory Master records. These indicate where the container or bihliographic item is physically located. A few representative records are shown below.

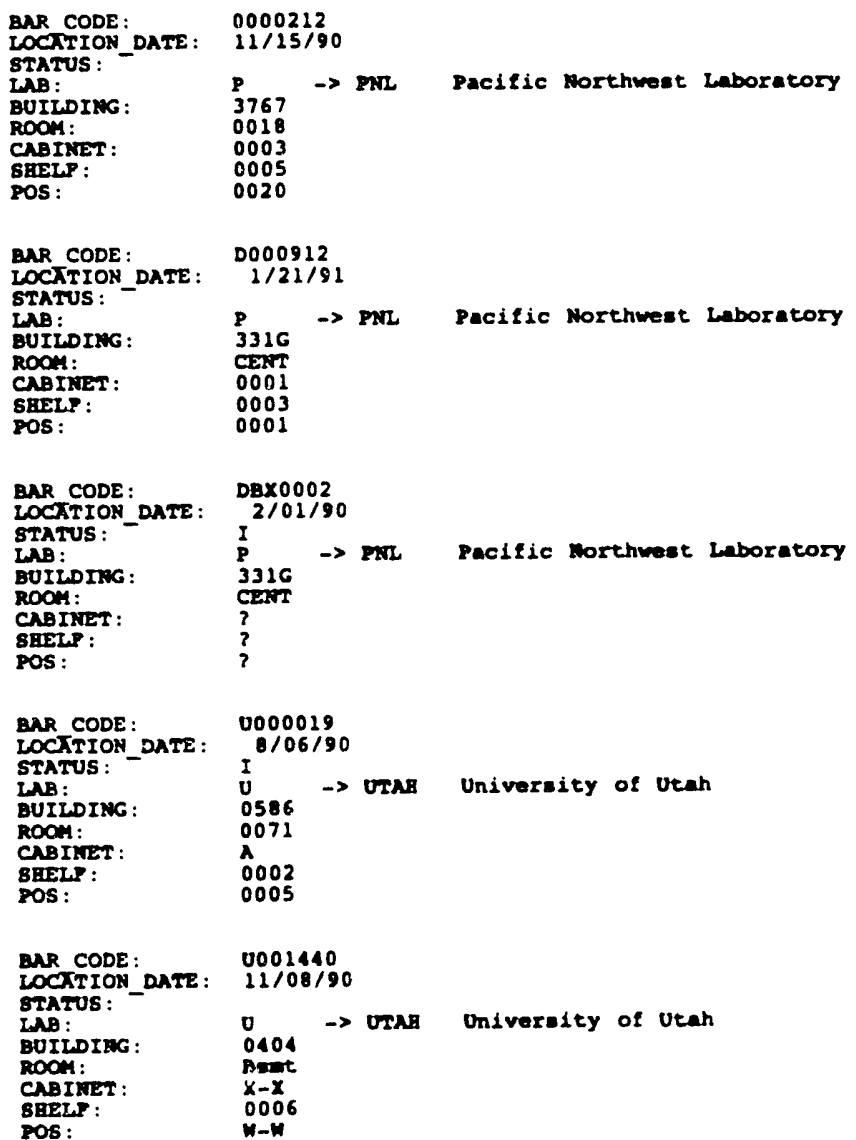


Detail

The introductory subset contains 135 Detail table records which relate individual animals to inventory bar codes. The example below illustrates how one bar code, D000912, can have many associated detail records. In this case, D000912 is the bar code label applied to a plastic tub containing many bags of tissue specimens. Each bag is associated with a single dog.

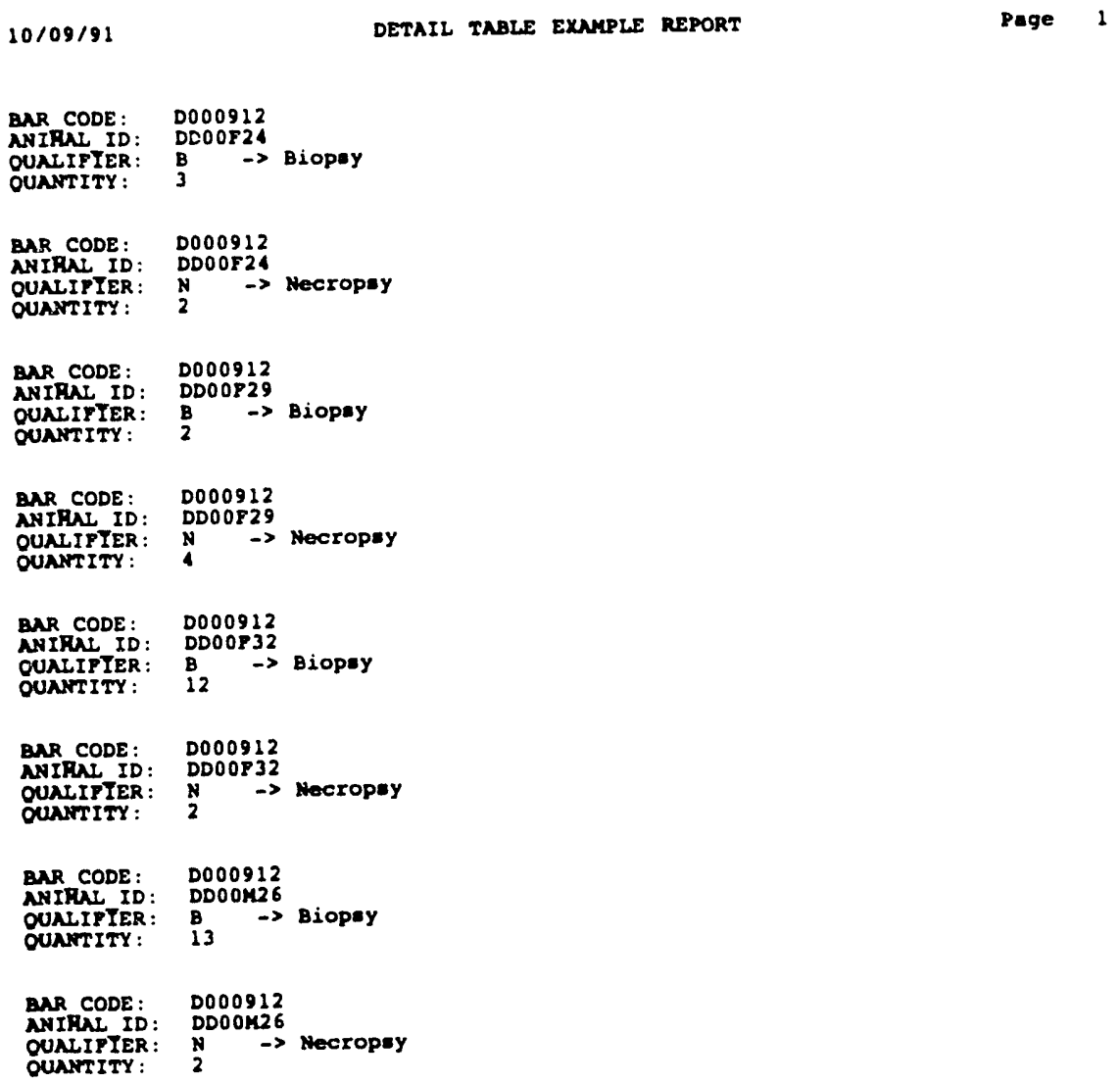

\section{Bibliography} Database

\section{Loan}

The Loan table will not be included in the NRA Distributed Access package. Printed information about loans may be obtained on request.

\section{Patron}

The Patron table will not be included in the NRA Distributed Access package. Printed information about patrons may be obtained on request.

The Bibliography database consists of 4 tables, only 2 of them are in use. At this early stage in its development, the bibliography database requires less than 1 megabyte of disk space at the NRA. One hundred records were selected for the introductory subset, they occupy less than 250 kilobytes of storage space.

\section{Book}

NRA Divtributed Access October 16, 1991 
The introductory subset contains 100 records from the Book table. These hold general bibliographic information for each item in the documents archives.

The books are related to physical location in the inventory database by the bar code label. Two records are shown below.

$10 / 09 / 91$

BOOR TABLE EXAMPLE REPORT

Page 1

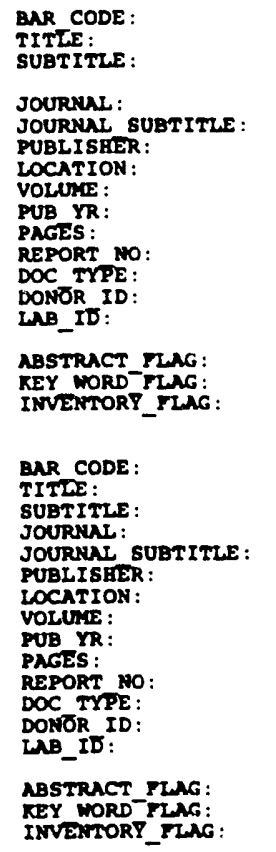

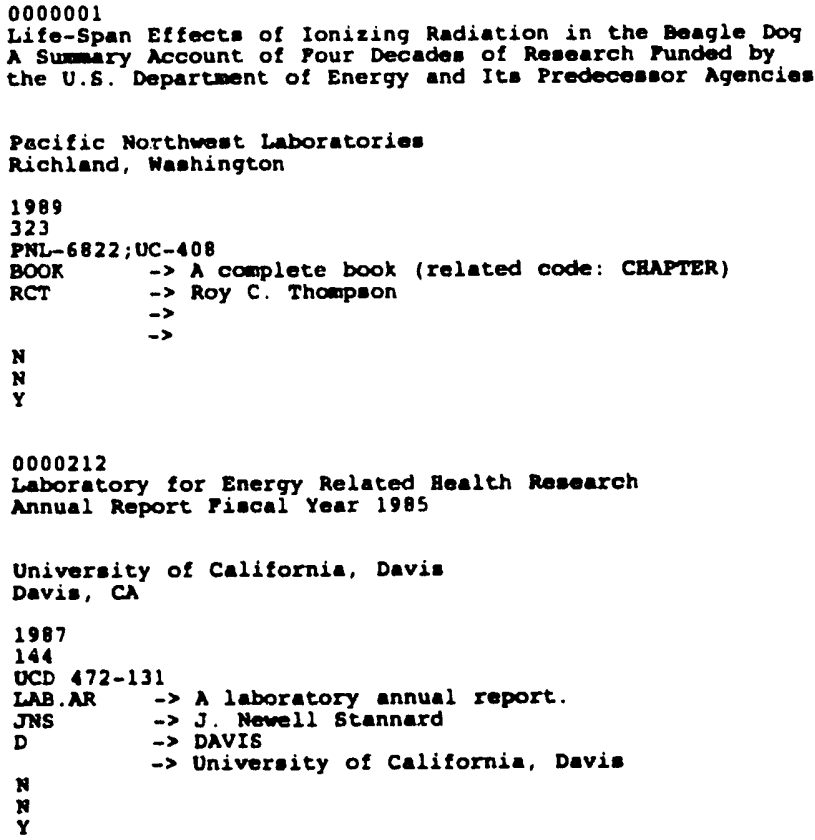

Author

The introductory subset contains 147 records from the Author table. These contain names of authors as shown below.

$10 / 09 / 91$

AUTBOR TABLE EXMULE REPORT

Page 1

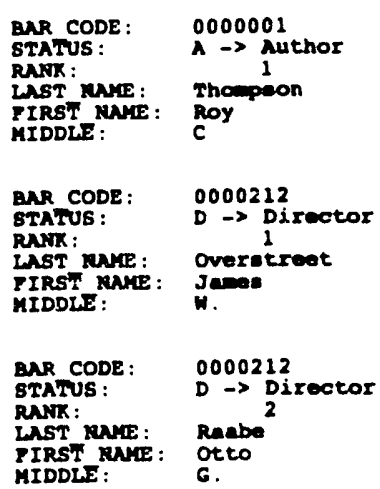


Key Word

The Key Word table is not implemented.

Abstract

The Abstract table is not implemented. 
Help screens are available at all times. They are invoked by pressing $\boldsymbol{F I}$. There are two types of help, menu related and cursor related.

Each menu has an option which will display textual help describing the menu and the contents of the database which may be examined through that menu. These help screens are printed on the following pages in alphabetical order.

Bibliography

If the user selects "Holdings" from the Bibliography Menu, the following text appears in a scrolling window:

MRA INFORMATION SYSTEMS

BIBLIOGRAPHY DEMONSTRATION

The NRA Information Systems include experimental design documentation, onimal sumaries, document catalogs, specimen catalogs, and bibliographic citations organized in this relational database. There are three major databases: the Dose-effects Summary, the Collection inventory, and the Bibliography. These are comonly referred to as the SUmMRY, IHVENTORY, and BIBLIOGRAPHY databases.

This demonstration BIBLIOGRAPHY database application contains representative records from two tables (BOOK and AUTHOR).

$$
\begin{aligned}
& \text { BIBLIOGRAPHY } \\
& \text { statis October 1, } 1991
\end{aligned}
$$

$\begin{array}{lcl}\begin{array}{l}\text { Table } \\ \text { BOOK }\end{array} & \begin{array}{c}\text { Records } \\ \text { Comments }\end{array} & \begin{array}{l}\text { Bibliographic citation, indexed by } \\ \text { bar-code label defined in Inventory } \\ \text { Database table Master. }\end{array} \\ \text { AUTHOR } & 480 & \begin{array}{l}\text { One or more records for each Book, } \\ \text { related by bar code label. }\end{array} \\ \text { KEY HORD } & \text { Not implemented. } \\ \text { ABSTRACT } & \text { Not implemented. }\end{array}$

Browsing through the BOOK Table you may view the outhor(s) in the corresponding AUTHOR Table. These Tables are also linked to the Location Table indicating the physical location of the book. Examples of these retrievals are included. You may obtain a subset of the bibliography based on:

$$
\begin{aligned}
& \text { TITLE } \\
& \text { AUTHOR } \\
& \text { YEAR }
\end{aligned}
$$


If the user selects "Cursor" from the Help Menu, the following text appears in a scrolling window:

\section{NRA INFORMATION SYSTEM} CURSOR CONTROL KEYS

You may move the cursor with the keytoard cursor control keys only; this software does not support use of a mouse or track ball.

The cursor controls, wich are available on any screen, are show at the bottom or at the top of the screen. Selection of an inappropriate cursor control key will couse a beep. The cursor controls are intuitive; they are slightly different depending on the type of screen you are viewing.

Menus:

$\begin{array}{ll}\text { The cursor is shown as a highlighted menu opt } \\ \text { Left arrow } & \text { Beep } \\ \text { Right orrow } & \text { Beep } \\ \text { Up arrow } & \text { Up one choice } \\ \text { Down arrow } & \text { Dow one choice } \\ \text { PgDn } & \text { Beep } \\ \text { Pgup } & \text { Beep } \\ \text { Home } & \text { Top choice } \\ \text { End } & \text { Bottom choice }\end{array}$

Help Screens:

The cursor is shown as a highlighted line of text, you may scroll up or down within the help window by using the cursor down or cursor up key.

$\begin{array}{ll}\text { Left arrow } & \text { Beep } \\ \text { Right arrow } & \text { Beep } \\ \text { Up arrow } & \text { Up one choice } \\ \text { Down arrow } & \text { Down one choice } \\ \text { PgDn } & \text { Scroll down one full window } \\ \text { PgUp } & \text { Scroll up one full window } \\ \text { Hone } & \text { First line of text } \\ \text { End } & \text { Last line of text }\end{array}$

Brouse Screen:

The cursor is shown as a small blinking underscore character (or some other symbol if you have customized the cursor display on your computer).

You moy use any of the arrow keys to move the cursor from field to field on the screen, wile the Pgup. PoOn, Home and End keys scroll the records in the database.

You may use the F3 or F4 keys to move the cursor to a different window on the browse screen.

$\begin{array}{ll}\text { Left arrow } & \text { Next field to the left } \\ \text { Right arrow } & \text { Next field to the right } \\ \text { Up arrow } & \text { Up one field } \\ \text { Down arrow } & \text { Dow one field } \\ \text { PgOn } & \text { Next RECORD } \\ \text { Poup } & \text { Previous RECORD } \\ \text { Home } & \text { First RECORD } \\ \text { End } & \text { Last RECORD }\end{array}$


The NRA data includes PARADOX tables and documentation of laboratory specific information. These tables are donated by the laboratories in the format information. The MRA has transformed these to wich is most convenient and compiled detailed documentation of the fields and relationship between fields in them.

THESE DETAIL TABLES ARE NOT SUPPLIED WITH THIS DEMONSTRATION

The most extensive collection of detail tables is that donated by the University of Californis at Davis. The list below illustrates the breadth of this collection.

Documented Davis Detail Tables

\begin{tabular}{|c|c|c|}
\hline Table Nane & Rows & Comments \\
\hline BOWES & 380 & Summary of bone related effects. \\
\hline COBALT_C & 222 & $\begin{array}{l}\text { One demographic record per dog in the } \\
\text { Cobslt study. Source of sparse records in } \\
\text { ANI_D for study } 05 \text {. }\end{array}$ \\
\hline$C O D$ & 1263 & $\begin{array}{l}\text { SNOOOG coded cause of death as printed in } \\
\text { annual report table. }\end{array}$ \\
\hline COMP & 11582 & $\begin{array}{l}\text { SNOOOG covied complaint portion of POAR, } \\
\text { used as source of TEFFECT. }\end{array}$ \\
\hline CS_ALL & 1078 & $\begin{array}{l}\text { One demographic record per dog in studies } \\
02,03, \text { and } 04 \text {. Source of most fields in } \\
\text { ANI_D for those studies. }\end{array}$ \\
\hline DIAG & 15227 & $\begin{array}{l}\text { SNOOOG coded diagnosis portion of POMR, } \\
\text { used as source of TEFFECT. }\end{array}$ \\
\hline DOSIMETR & 852 & $\begin{array}{l}\text { Dosimetry table developed by Otto Raabe. } \\
\text { Source of WGT_FIRST_INSULT in ANI_D }\end{array}$ \\
\hline hISTO & 19402 & $\begin{array}{l}\text { SHODOG coded histopathology in multi-record } \\
\text { "medical story" format. Used as source for } \\
\text { TEFFECT. }\end{array}$ \\
\hline MISSTISS & 8630 & $\begin{array}{l}\text { Catalog of ANIMAL_ID and SNOOOG topography } \\
\text { codes for which exhaustive physical search } \\
\text { failed to locate tissue specimen in Davis } \\
\text { archives. }\end{array}$ \\
\hline NOTUMORS & 3967 & $\begin{array}{l}\text { Animals with non-neoplastic problents, } \\
\text { developed by Bill Spangler. }\end{array}$ \\
\hline POAR & 10119 & $\begin{array}{l}\text { Problem Oriented Medical Record developed } \\
\text { by Russ White. Summarizes each medical } \\
\text { problem in studies 02, 03, and O4 using } \\
\text { simple coding system. See COMP and DIAG for } \\
\text { SNOOOG entries. }\end{array}$ \\
\hline TUMORS & 3646 & $\begin{array}{l}\text { Description in English of tumors found in } \\
\text { biopsies and at necropsy. Developed by } \\
\text { Roger Culbertson. }\end{array}$ \\
\hline TUMOR_MI & 2990 & $\begin{array}{l}\text { Identical to TUMORS, but restricted to non- } \\
\text { primary tumors. }\end{array}$ \\
\hline WEIGHTS & 953 & Terminal organ weights in grans. \\
\hline
\end{tabular}




$\begin{array}{lrl}\text { XRAY_CS } & 352 & \begin{array}{l}\text { One demographic record for each dog in } \\ \text { study } 01 . \text { Source of sparse records in } \\ \text { ANI_D for study 01 }\end{array} \\ \text { XRAY_TUM } & 10643 & \text { Similar to Tumors. }\end{array}$

Function Keys

If the user selects "Function" from the Help Menu, the following text appears in a scrolling window:

NRA INFORMATION SYSTEMS FUNCTION KEYS

ESC The ESC ("Escape") key is used to bring back the previous screen.

F1 The F1 ("HELPM) key may be used at any time to obtain on-screen help.

F2 The F2 ("DO IT!") key is used to start a search from a search criteria setection screen.

F3 The F3 (mUP IMAGE") key is used to move up one table on a browse screen. You can press F3 or F4 to move the cursor anong the tables on the browse screen. F3 key actions are cyclic. Repeated use of $F 3$ will cycle the cursor position through oll the tables on the browse screen.

F4 The F4 ("DN IMAGE") key is used to move down one table on a browse screen. You can press F4 or F3 to move the cursor mong the tables on the browse screen. F4 key actions are cyclic. Repeated use of F4 will cycle the cursor position through all the tables on the browse screen.

F5 The F5 ("CLINICAL TEXT") key is used to open a view window showing the clinical text associated with an animal. The F5 key is only functional on browse screens.

F6 The $F 6$ ("PRINT") key is used to send reports to a file or the printer. This is not the equivalent of the Dos Print Screen button; F6 produces an expansion of all the scrolling images on the screen.

F7 through F12 The remaining function keys are not activated. 
The NRA holdings inventory database contains information about materials in the Records Repository and the Tissue Archives. The organizing concept is the bar code label which is associated with each item or a container of items. A single bar code is related to an individual document in the records repository, or associated with a container holding tissue specimens.

This demonstration application contains representative records from the inventory database. Simple searches by BAR COOE and ANIMAL_ID are provided. The following table illustrates the scope of the NRA Inventory Database:

\section{NRA Database Status}

October 1, 1991

Bar-Code Labels:

Recipient of Pre-printed Labels

Label Range

ANL: T. Fritz, D. Doyle

DAVIS: J. Parks, O. Raabe

ITRI: B. Boecker

LBL: P. Durbin

NRA Document Archives: E. Ligotke

MRA Specimen Archives: L. Smith

NRA Specimen Archives: L. Smith

PHL: G. Dagle

UTAH: S. Miller, H. Angus

Inventory Database:

$\begin{array}{lc}\text { Table Nane } & \text { Records } \\ \text { MASTER } & 3224 \\ \text { LOCATION } & 3251 \\ \text { DETAIL } & 122259\end{array}$

PATRON

1

LOAN

Comments label.

$\begin{array}{lr}\text { STANNARD } & 369 \\ \text { DAVIS } & 137 \\ \text { PNL } & 1240 \\ \text { UTAH } & 1482\end{array}$
containers of materials.

$\begin{array}{ll}\text { DAVIS } & 2746 \\ \text { PNL } & 1240 \\ \text { UTAH } & 8243\end{array}$

Similar to a Library Card.

\begin{tabular}{|c|c|c|}
\hline $\begin{array}{l}A 000001 \\
D 000001 \\
1000001 \\
\text { LBL0001 } \\
0000001 \\
\text { D8X0001 } \\
\text { D000901 } \\
\text { P000001 } \\
\text { U000001 }\end{array}$ & $\begin{array}{l}A 000900 \\
D 000900 \\
1000360 \\
L B L 0360 \\
0000900 \\
D B X 0064 \\
D 001260 \\
\text { P003105 } \\
\text { U001801 }\end{array}$ & $\begin{array}{r}7 / 1 / 90 \\
9 / 10 / 90 \\
1 / 11 / 91 \\
12 / 4 / 90 \\
9 / 10 / 90 \\
8 / 1 / 90 \\
11 / 15 / 90 \\
6 / 11 / 91 \\
9 / 10 / 90\end{array}$ \\
\hline
\end{tabular}

One record per document in the Documents Archives or container in the Specimen Archives. Each document/container and Master record is identified by a bar code

One or more records for each Master, additional record whenever container is moved or loaned.

One or more records for each Master relating individual animals to

Relates Master to Patron when materials are on loan. REECo JWS Boxes 


\section{MRA INFORMATION SYSTEMS}

GENERAL DESCRIPTION

The Mational Radiobiology Archives (NRA) project is a comprehensive effort to gather, organize, and catalog original data, representative specimens, and other' suporting materials related to significant radiobiology studies. This provides researchers with information for analyses wich compare or conbine results of these and other studies and with materials for analysis by advanced molecular biology techniques. The NRA has concentrated on studies of animals exposed to ionizing radiation at Argonne Mational Laboratory, Oak Ridge National Laboratory, the Inhalation Toxicology Research Institute, the Pacific Northwest Laboratory, the University of California at Davis, and the University of Utah.

The NRA utilizes a three task approach to organize materials from diverse sources. These are the Informational Systems Computer Database, the Tissue Archive and the Document Archive. The Infermational Database, Document Archive and Tissue Archive are maintained through bar code readable labels.

The MRA Information Systens includes experimental design documentation, animal summaries, document catalogs, specimen catalogs, and bibliographic citations urganized on a microcomputer. We work closely with database managers at the participating laboratories to insure that electronic information is accurately translated into the NRA format.

The initial donation to the MRA Document Archives includes the collection of documents from J. Newell stamard in support of his book, RADIOACTIVITY AMD HEALTH, A HISTORY.

The MRA Specimen Archives has received more than 1000 dog tissue specimens and histopethology blocks from DAVIS. The specimens are organized and housed in a protected environment.

Computer database sechnology is essential to integrating such a broad and Jiverse collection of information. The MRA staff are developing several inter-related databases, each follows the relational model. There are three major databases: the Dose-effects Sumnary, the Collection Inventory, and the Bibliography. These are commonly referred to as the SUMUARY, INVENTORY, and BIBLIOGRAPHY databases.

This demonstration application contains paired-down version of the MRA Information System. It is designed to show the scope of the system by allowing the user to browse records with the databases associated main forms. Several simple searches have been included to illustrate potential data extractions.

The following table illustrates the scope of the MRA summary database:

Sumary Database:

$\begin{array}{llr}\text { Table } & \text { Lab Neme } & \text { Records } \\ \text { LAB } & & 6 \\ \text { STUdy } & & 60 \\ \text { GROUP } & & 444 \\ \text { ANImel } & & 14700 \\ & \text { ANL } & 108 \\ & \text { DAVIS } & 1437 \\ & \text { ITRI } & 1645 \\ & \text { ORNL } & 9765 \\ & \text { PNL } & 498 \\ & \text { UTAH } & 1247 \\ \text { TDOSE } & & 1886 \\ & \text { DAVIS } & 863 \\ & \text { UTAH } & 1023 \\ \text { TEFFECT } & & 41092 \\ & & \\ & \text { ANL } & 820 \\ & \text { DAVIS } & 915 \\ & \text { ORNL } & 11813\end{array}$


FUACTION

CONTROL

AML

DAVIS

ITRI

ORNL

PNL

UTAH
19308

908

120

219

266

3579

130
Purpose

MRA INFORMATION SYSTEMS

PURPOSE

This software is a demonstration program showing the eype of information available in the Mational Radiobiology Archives Information System. available in the National Radiobiolected fields in the major tables.

Data searches are provided for answering simple queries. These queries

will extract a subset of the information to be viewed on the browse screen.

will extract a subset of the information more information than will fit on

the browse screen.

A representative subset of the MRA Informational Database is distributed with this program. The user will be able to "play" with this subset and determine what type of data request would be most useful from the full MRA Information System.

Address requests to:

Dr. Charles R. Watson, Ph.D.

Director, National Radiobiology Archives

Pacific Northwest Laboratory

P.O. Box 999 P7-82

Richland, WA 99352

Telephone: (509) 376-3483

FAX:

(509) $376-4533$ 


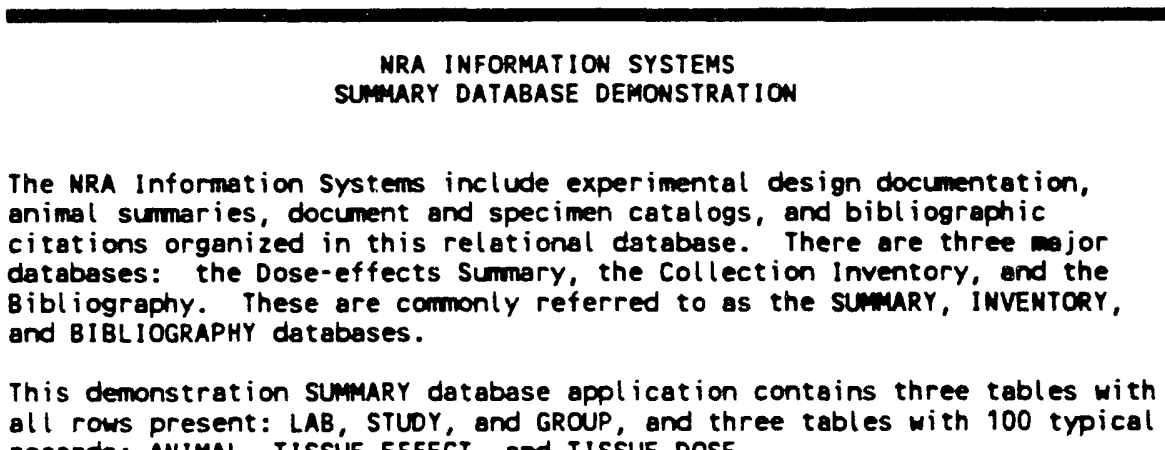
all rows present: LAB, STUOY, and GROUP, and three tables with 100 typical records: ANIMAL, TISSUE EFFECT, and TISSUE DOSE.

The following table illustrates the scope of the NRA summary database:

SUMMARY DATABASE

Status October 1, 1991

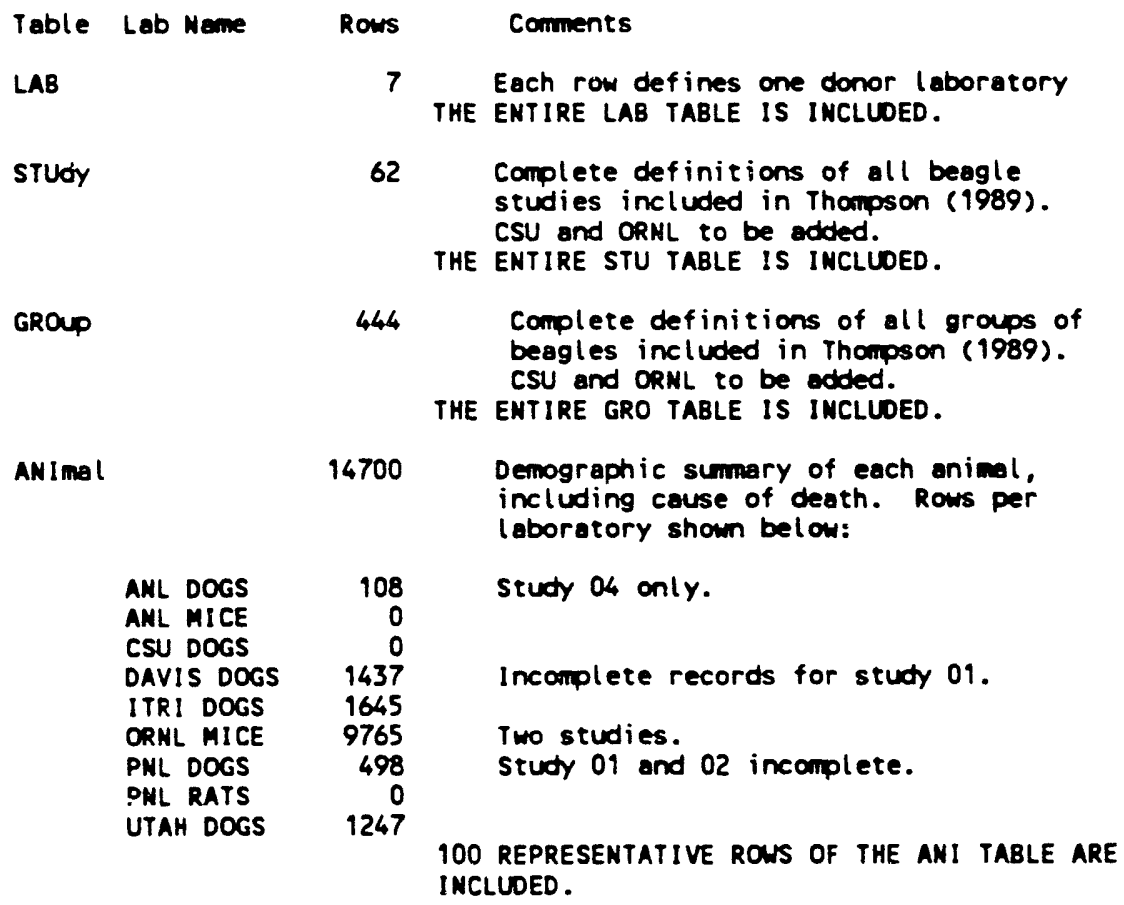

TDOSE $\begin{array}{rr}1886 \\ \text { DAVIS } & 863\end{array}$ UTAH 1023

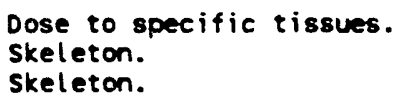

100 ROWS OF tDOSE TABLE ARE INCLUDED.

TEFFECT

ANL

DAVIS

ORNL

UTAF
41092

820

9151

11813

19308
Effects summarized by tissue and morphology categories.

699 ROWS OF TEFFECT TABLE ARE INCLLOED.

Dose to tissue category as anction of time. 
THE FUNCTION TABLE NOT INCLLDED.

CONTROL

One record for each use of a control animal on a study. Some animals were controls for more than one study.

$\begin{array}{lr}\text { ANL } & 120 \\ \text { DAVIS } & 219 \\ \text { ITRI } & 266 \\ \text { ORNL } & 3579 \\ \text { PNL } & 130 \\ \text { UTAH } & 173\end{array}$

UTAH

109 ROWS OF CONTROL TABLE ARE INCLUDED.

You may browse rows in the ANIMAL table using a screen showing associated rows of the LAB, STUDY, GROUP, TISSUE DOSE, and TISSUE EFFECT tables.

You may search the demonstration database for subsets of rows based on:

ANIMAL ID

ASSIGNED ID

STUDY NAME

TISSUE EFFECT SUmary Category

TISSUE DOSE SUmmary Category 
There is help available for all positions of the cursor on the browse screens. The fields are presented in alphabetical order below. Many of these fields appear on several browse screens, so no attempt has been made to relate the field to a position on the screen.

\section{Accession date}

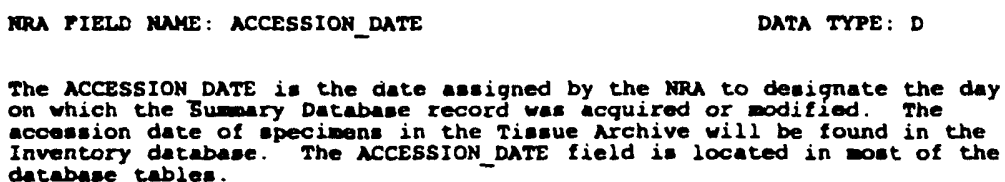

Animal ID

BRA PIELD MARE: NNIMAL_ID

DATA TYPE: $A 8$

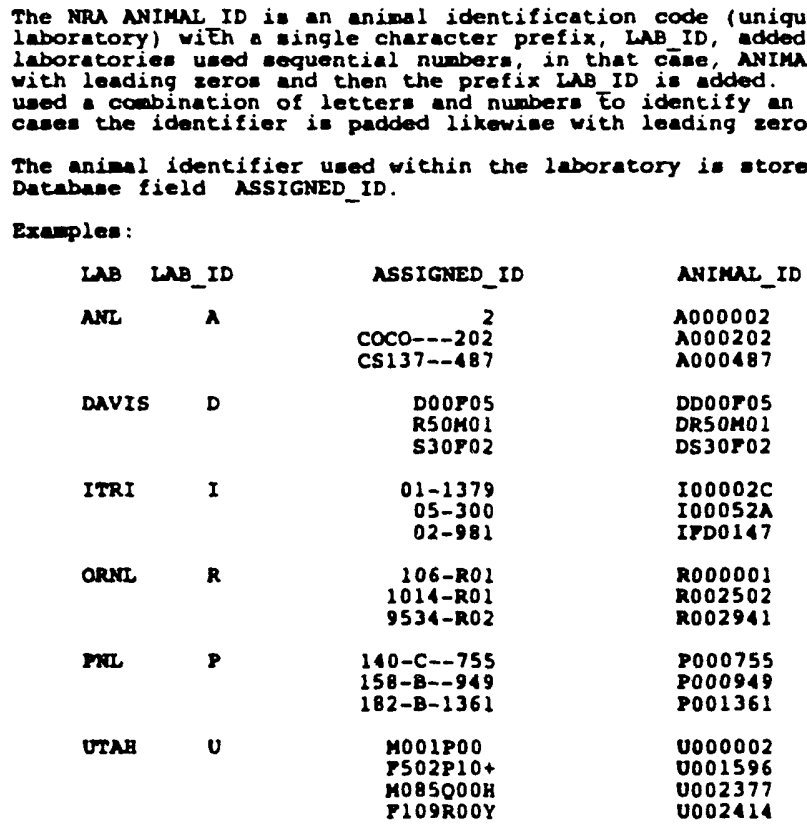


Animal

Quantity

\section{Assigned ID}

\section{Bar Code}

NRA PIELD RAME: ASSIGNED_ID

DATA TYPE: A10

The ASSIGNED ID is the animal code used by the donor laboratory to refer to apecific añimal. If the laboratory used a tudy dependent animal

identification cheme, the ASSIGNED ID is taken from laboratory usage.

ther laboratoriss used the animal tatt $\infty$ as the research animal identifier.

in that case, the $\lambda S S I G N E D$ ID 1 a combination of the experiant nase

animal catcos.

The animal identifier used within the NRA surosary database is stored in

The animal identid

Examplea

\begin{tabular}{|c|c|c|c|}
\hline LAB & LAB_ID & ASSIGNED_ID & ANIMAL_ID \\
\hline NRR & $\boldsymbol{A}$ & $\begin{array}{l}\operatorname{coco}=-202 \\
\operatorname{cs} 137--487\end{array}$ & $\begin{array}{l}1000002 \\
1000202 \\
1000487\end{array}$ \\
\hline DAvIS & D & $\begin{array}{l}\text { DOOPOS } \\
\text { R5OMO1 } \\
\text { S30802 }\end{array}$ & $\begin{array}{l}\text { DDOOFOS } \\
\text { DR5OM01 } \\
\text { DS30P02 }\end{array}$ \\
\hline ITRI & I & $\begin{array}{r}01-1379 \\
05-300 \\
02-981\end{array}$ & $\begin{array}{l}\text { I000002C } \\
\text { I00052A } \\
\text { IPD0147 }\end{array}$ \\
\hline ORNI & $\mathbf{R}$ & $\begin{array}{r}106-R 01 \\
1014-R 01 \\
9534-R 02\end{array}$ & $\begin{array}{l}\text { R000001 } \\
\text { R002502 } \\
\text { R002941 }\end{array}$ \\
\hline$P 2 \sqrt{2}$ & P & $\begin{array}{l}140-C--755 \\
158-B--949 \\
182-B-1361\end{array}$ & $\begin{array}{l}P 000755 \\
P 000949 \\
P 001361\end{array}$ \\
\hline UTAB & v & $\begin{array}{l}\text { M001P00 } \\
\text { P502P104 } \\
\text { M0850008 } \\
\text { P109R00Y }\end{array}$ & $\begin{array}{l}0000002 \\
0001596 \\
0002377 \\
0002414\end{array}$ \\
\hline
\end{tabular}

WRA TIELD RAVE: BAR_CODE

DATA TYPE: $A 7$

Bar CODE is unigue label applied by the MRA to materials or containers of aterials in the Tianue Archives or the Document Archives.

Inventory Usage:

The BAR CODE is the unique identiflier of physical object such an a the

MSTER, DETAIL, and LOCATION tables.

Bibliography Uaege:

The $B A R$ CODE is the unique identifier of a document and is linked to

che the in

the MSTER and LOCATION tables for each BOOK record.

Label generation:

are printed by the MRA. A block of labols and

asoociatod data entry forne my be requestod. 
Birth Date

\section{Building}

Burden Type

Cabinet

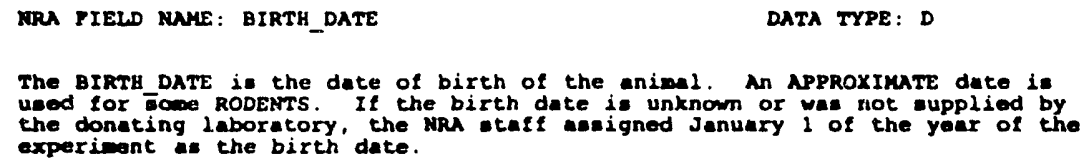

DATA TYPE: D

The BIRTH_DATE is the date of birth of the animal. An APPROXIMATE dute is used for the RODENTs. If the birth date is unknown or was not ouppliod by axperiment as the birth' date. tored.

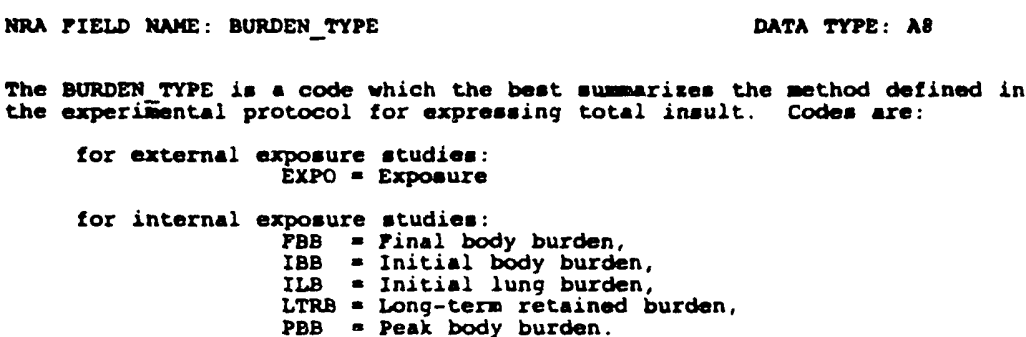




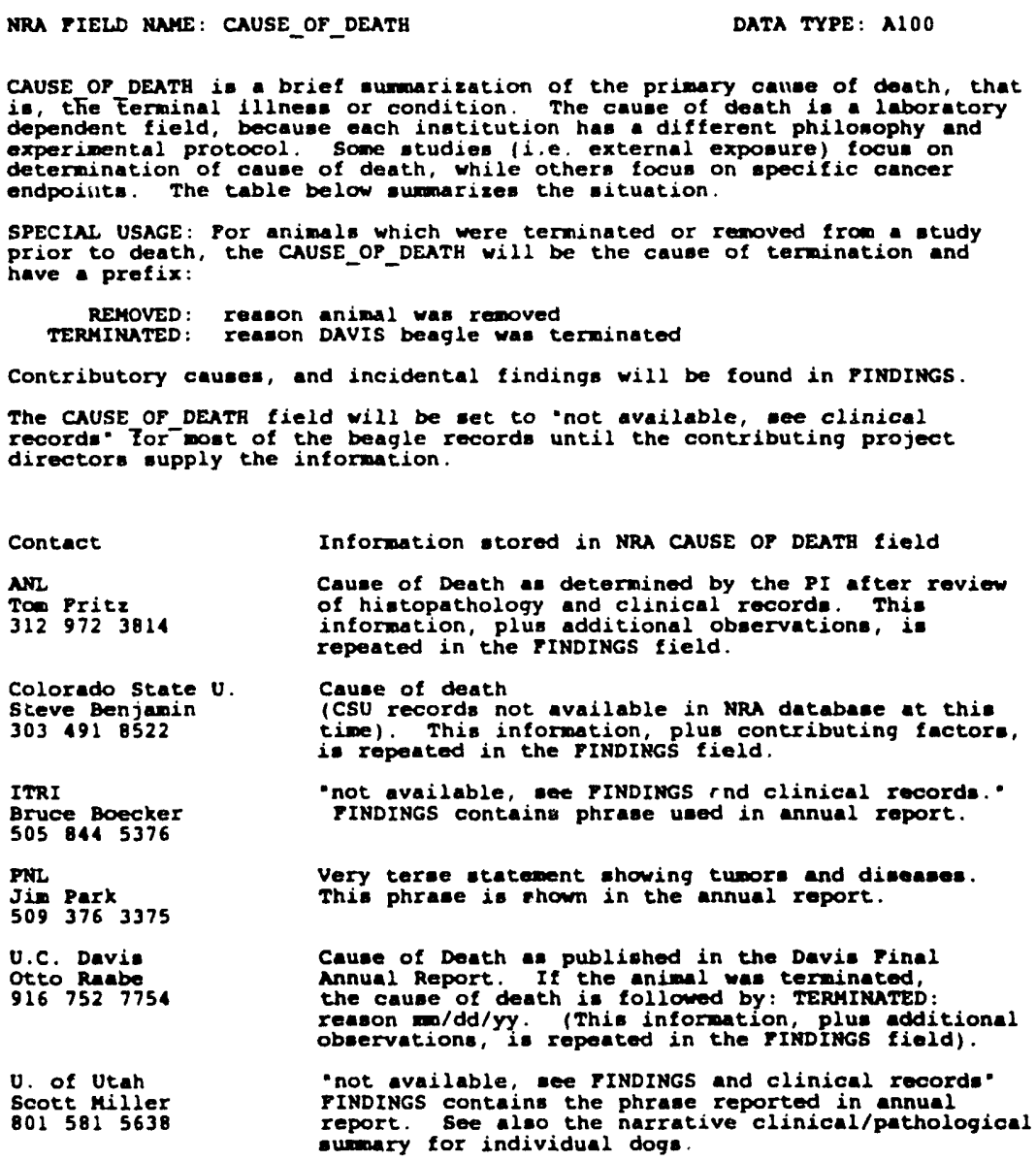

Contact

ANL

Tom Pritz
$312 \quad 972 \quad 3814$

Colorado state $U$. Sreve Benjanin
3034918522

ITRI

Bruce Boecker
5058445376

PNL

Pin Part

Jim Park
5093763375

U.C. Davis

Otto Raabe
9167527754

v. of Utah

Scott Miller
8015815638

Information stored in NRA CAUSE OP DEATH fielo

Cause of Death as determined by the PI after roview

of histopathology and clinical rocords. This repeated in the FINDINGs field.

Cause of death

(CSU records not available in NRA database at this time). This information, plus contributing factore, is rapented in the FINDINGS field.

- not available, we PINDINGS rnd clinical recorda." FINDINGS contains phrase used in annual report.

Very terse etatement showing turore and dimenses. This phrase is show in the annual report.

Cause of Death as published in the Davis Final Annual Report. If the animal was terminated. the cause of death is followed by: TERMIMATED reason $\mathrm{wdd} / \mathrm{yy}$. (This information, plus odditional
observations, is repoated in the FINDIMGs field).

- not available, we FINDINGS and clinical records" FINDINGS contains the phrase reported in annual
report. See also the narrative clinical/pathological report. Soe also the narrativing for individual doga.

\section{Comments}

\section{Container}

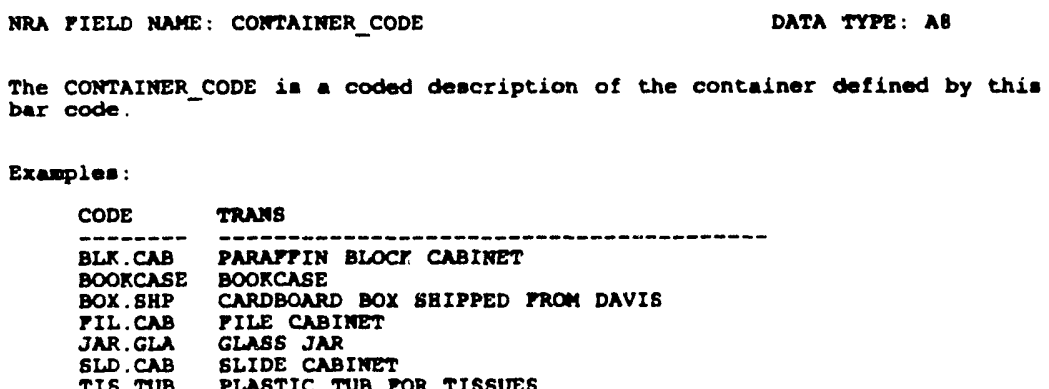




\section{Control}

MRA PIELD MUNE: CONTROL

DATA TYPE: A1

CONrRol is a (Y)es/(N)o llag answering the question whether or not the anianl in considerod a control animal. Most control animals were aneignod to a pocilic tudy, however, wome controls are part of a general control

Dam ID

RRA FIELD MANE: DNY_ID

DATA TYPE: AT

The DAM ID is an alphanuworic code anigned by the contributing laboratory to the dan (wother) of the aniond. Unknown data are left NuIL.

If possible, the DNM ID corresponds to ANrunt ID in tormat, and the Das is iteelf represented in the suwary Databane. Bowever, not every DAM ID will have corresponding row in the ANIMAl table bocause anionis acquired oarly colony. In that case, the DNM ID will confore to donating laboratory unage.

Death Date

NRA PIEID MAME: DEATH_DATE

DATA TYPE: D

DEATR DATE is the dute the animal died or was euthanized. Live animals and many removed animale have the DEATB DATE set to sulu rewoved way or not have DEATH_DATE, depending on the degree of follow-up by the laboratory.

Exnmples:

DISPOSITION

A (Accidental)

D (Died)

E (Euthanizod)

(Euthanizod)

(Stiliborn)

(Removed)

Tuth (indicating Live
REMOVED_DATE

Nurn

NULL

NuLt

NuLL

NOT NULL

NOT NULI

NoT NuLI
NuLL.
DEATH_DATE

Nor NuLis

HOT NULI

NOT NULI

NoT NuLl

uauelly NurL

NOT NuLL (Lab has information) not NuLL 
Disposition

\section{Document Type}

\section{Donor}

\section{Identification}

Final Insult

Date
DISPOSITION is an alphenumeric code describing the death or removal of the Diniant.

Codes are:

$A=$ accidental

died,

- euthanized.

S renoved (CULLED)

cerminated (a DAvIS secific code which indicates the date of anputation of a leg. It is sesuned that the dog would have died on the termination date).

$x=$ tiliborn.

Live animals and those with unknown data have DISPOSITION set to wull.

NRA PIELD NAKE: DOC_TYPE

DATA TYPE: AB

The DOC_TYPE is a code for the type of document.

Exarplea:

CODE

TRANS

BOOR

complete book or conference proceedinge.

A complete journal.

REPORT $\quad \hat{A}$ report, generally unpublighed

NRA PIELD NAME: DONOR_ID

DATA TYPE: A3

The DOWOR ID is a 3 character intelligent code for the donor of a Bibliography item.

Examples:

CODE TRANS

BBB Bruce B. Boocker

Charles $R$. Watwon

J. Nowell stannard

Otto G. Raabe

Roy C. Thompon

DATA TYPE : D

The PINuL INsULT Date is the day the inault terminated. If the animal was the anisal was given a eingle ineult, rikni_INsULT is eet oqual to FIRST INSURT.

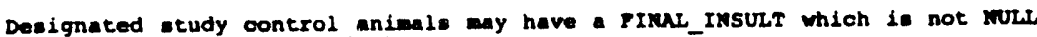
but is eet to the date of oham exposure.

The age at FINRL_InsulT is computed by subtracting PINAL_Insult from BIRTH_DATE 
Findings

First Insult Date

First Name

\section{Group \\ Identification}

PINDIMGs is a brief oumarlzation of the oignificant finding for an animal. Clinical phrases are separated by ' $; '$ '. Includad in PIMDINGs will bo the one publiahed in laboratory ennual reporte. Il no information is avallable. PINDIMGS Will be eet to kULh. If the animal was alive on the coosesion date, FINDINGS will be set to Living on NRA Acceseion Date".

PInDIMcs is - multipurpose taxt $\mathrm{lield}$, but some codes and ayntax has been added by the NRA.

codes uned in rINDIMGS

COD: Cause of Death (Davie)
COT: Cause of Termination Eron study (Davis)

Information in the FINDINGS is not necosentily the CAUSE of DEATR. In -am atudies (for example, the boagle inhalation tudiea), the cause of death ay have been unrelated to the experimental insult and was not ascertained cause of DEATH, if knom, le elvaye the firet phrase in the PINDINGs flold.

WRA PIELD MANE: PIRST_INSULT

DATA TYPE: D

PIRST INSULt is tha date of the firet experimental inoult. If the animal was not inaulted or the date is unknown then PIRST_INSULT io left wish. Designated study control anima wa have a FIRST_INSULT wich is not wul but in set to the date of has exposure.

The age at FIRST_INSULT is computed by oubtrecting the PIRST_InsUlT fro the BIRTH_DATE and converting roo days to years.

There is a companion field: PIRul Insult which is the day the intult

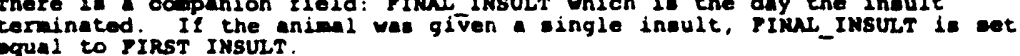

DATA TYPE: A15

ITA PIELD MUE: PIRST MANE

PIRST WuE is the firat name of the author.

WRA PIELD MNE: GROUP_ID

DATA TYPE: A2

The GROUP_ID is the identifier for group of animale within a etudy consisting of a two digit (zero-filled) number between "00" and" $99^{\circ}$, atored a. ASCII characters. The combination of LAB_ID, STUDY_ID and GROUP_ID Will be unique.

For beagles, GROUP ID codes were assigned based on the row number of the tables found in appendix B of Roy Thompen's book. GROUP_ID $900^{\circ}$ is ueed cor undelo Thomeon' book. Typically, these are non life-apan animale.

For rodents, GROUP ID oodes were ansigned based on discuselions with the donating invertigaEor. 
Insult Units

NRA FIELD NAME: INSULT_UNITS_SI

DATA TYPE: AB

The unite of the ineult in 81 units. Control or unknown data are left wubl.

The following insult unite are dofined

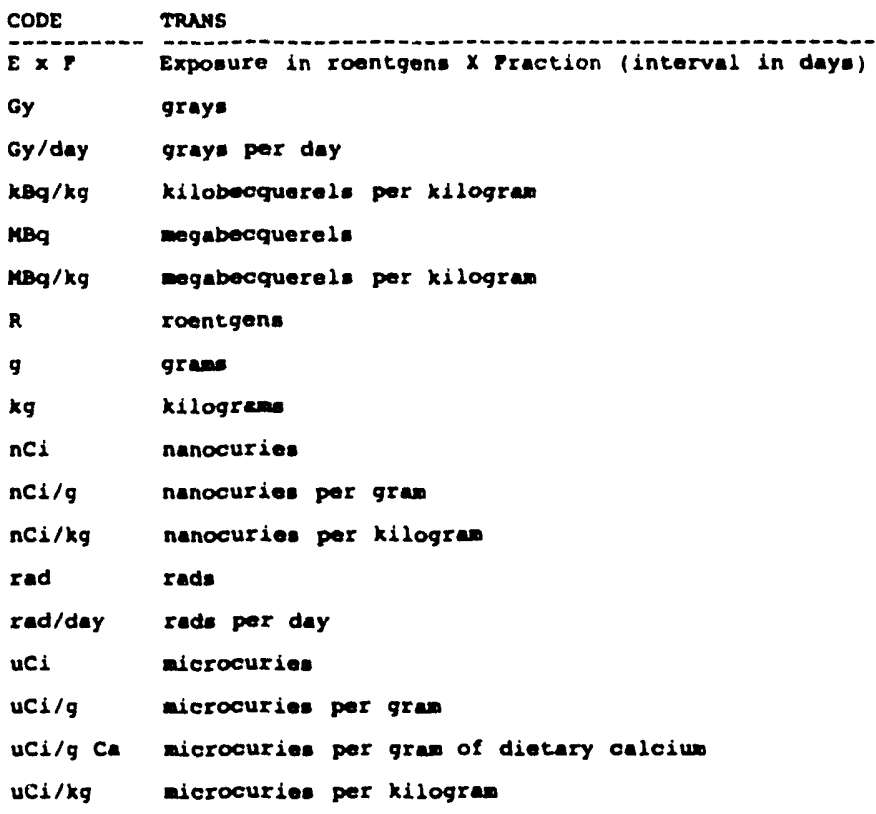

Item

MRA FIEW WUE: ITEH_CODE

The ITEM_CODE is a ooded description of the inventory 1te.

Exnmples:

CODE

BI0.10

BLX. PAR

BON.ALC

BON. FOR

BOOK.REC

JoUruy

IAB.AR

REPORT

SLD. PAR

SLD. RAD

TIS.ANC

TRANS

DOC

PARAPPIN BLOC

PONE SPECIMEN IN ALCOHOL

BONE SPECIMEN IN FORHLIN

BOOR IN THE BIBLIOGRAPBY DATABASE

CLINICAL RECORDS

BIBLIOGRAPHY DATABage

REPORT IY THE BIBLIOGRAPRIC DATABASE

PARATTIN SLIDE

SLIDE RADIOGRAPB

TISSUE SPECIMEN IN NCOAOL
IISSUE SPECIMEN IN PORHLI 
Item Quantity

Journal

Lab

\section{Laboratory Identification}

Last Name

Litter Number

Middle Initial
MRA TIEL MUE: ITH_OTY

DATA TYPE:

The ITEM ory is the approximate quentity of iteme in this bar coded containe $\bar{r}$ or unit.

TRA PIEL MNE: JOURNA

DATA TYPE: A120

Jounul is a taxt atring containing the title of the journal

URA TIELD WANE: LAB

DATA TYPE: Al

The LAB field is a code indicating the location of inventory item

Exapples:

$P=$ PNR
UTAH

LITTER NO is an alphanumeric code aseigned to each litter within a colony

LITTER NO is an alphanumeric code with leading geroe. Unknown data are loft mul. 
Morphology

Category

\section{No Help \\ Available}

\section{Pages}

\section{Position}

The Norphology catogory is a sNodog cme. Norwally, the uner will wee the tranclation.

The TISSUE EFFECT (TEFTECT) table umarizes the of foct observed in

-ignificane tiasue categoriea for aach animal. It containa fros soro to

-everal row per enieal. por anciliary inimal. (STUDY ID - "99") there are

zero row in the TISSUE EFrECT table, For other animala, there will be as

many rowe as neceseary to umearize che clinical and histopathological

obeervations.

The translated morphology catogories are:

Int lametion

Grouth ubnoralitie

Neoplacen, benign

Heoplasm, uncertain if benign

Careinom in it it

Malignant, primary

Malignant, contiguous epread

Malignant, microinvasive

Malignant, ctastatic

Malighane, roeurrene

Malignant, uncertain if primary

The tranalated tiesue categories are

skin and Memarie:

Bewato and RE syateon Blood

Lyoph nodes

musculonkeletal oyotes

Roapiratory oyate. upper

Rempiratory ayeted, lower

Urinary Tract, upper

Tract. 100

Reproductive

Nervous oyetere including eyes

MA PIELD MANE: none

DATA TYPE:

No help for this tield available.

MRA PIEID MNE: PAGES

DATA TYPE: A12

The proes field contains the nuaber of pages or a range as appropriate.

The pos is the ponition of the containar at the amalleat level of the locetion hierarchy.

DATA TYPE: A4

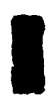


Primary

\section{Publisher}

Publication

Year

Quantity of Insult

\section{Qualifier}

The PRIMary field was designed as a $(Y) e w /(N) 0$ flug anowering the question wether or not a dog is considered part of the well-defined beagle life-apan -tudies. Rodents are all designated an PRIMNRY = " $\mathbf{~}$

Ancillury doge (not included in Roy Thompeon's book) uned for doeinetry or breoding purposes have PRIMARY tet to $\%$. Thase doge are included in the Sumary Datahase only to provide the full geneologic history of the colony.

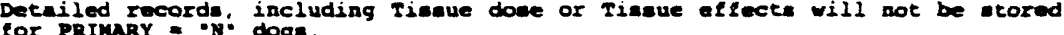

In prectice, wone doga not included in Roy's book (i.e. controls for $A$ 04) have PRIMARY $=\cdot Y$. based on discussion between the $\mathrm{kRM}$ ataff and the donating investigator.

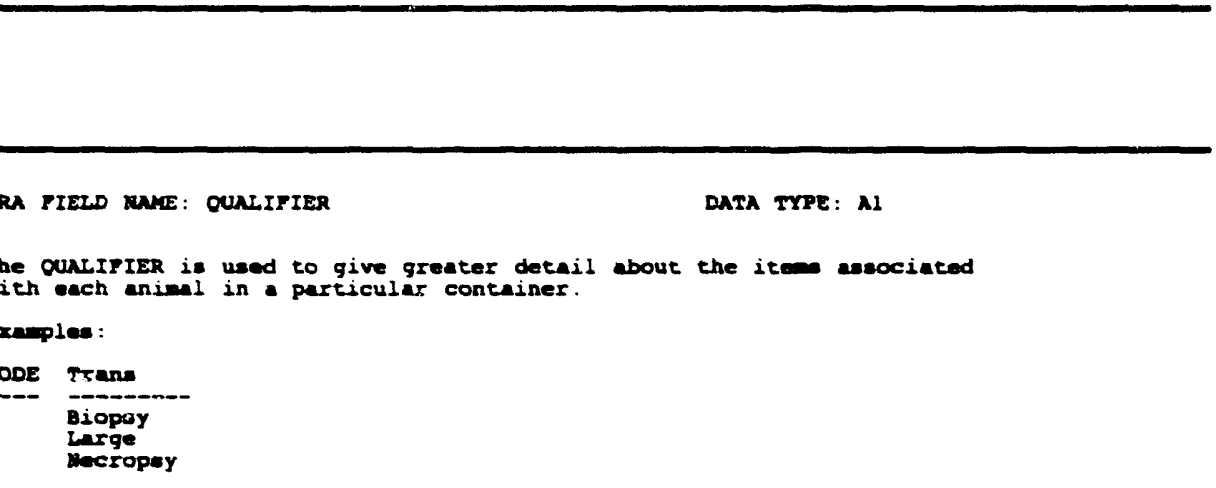


Quantity

Rank

\section{Removal Date}

Report Number

\section{Results Final}

Room

NRA Dieribued Access The ouAvrTY is the number of items ansociaced with the animal in this container. If this record has a

MRA FIELD MNNE: RANT

DATA TYPE: $N$

RAvs is a nueric code describing the wort order of this author in a multi-author docuent.
NRA TIELD MANE: REMOVNL_DATE

DATA TYPE: D

REMOVAI DATE is the date the animal was resoved from the experiment. REMOVAL DATE in set to NULI for AII enimals except those wich were ranoved from a Eudy Animals with a REMOVAL DATE include those transferred from any (lont to follow up) and thöes culled from the exudy in order to earigfy the protoco: Remoyal date has been used by DAvIs and uTAB for theit Beagle Dog etudies.

TIELD NAYE: REPORT NO

DATA TYPE: $\mathbf{4 0}$

The REPORT wo is the report number(a) of the document. Multiple report numbers aré separated by ": Character string. This nuaber is usually asisigned by the government of contracting agency. 
Sex

SEX is aingle charactar code for the sex of the animal. The codes are:

Shelf

Sire

Identification

Snodog

MRA PIELD NMVE: SIRE_ID

DATA TYPE: A7

The SIRE ID is an alphanumeric code assigned by she contributing laborator to the aire (father) of the animal. Unknow data are left MuLl.

If posaible, the SIRE_ID corresponds to ANIMUl_ID in format, and the sire is itself represented in the Surmary Database. However, not every SIRE ID vill have corresponding row in the ANImul table because animils acguired oarly in the history of a particular colony had parents wo were not part of the

MRA FIEWD MAKE: SNODOC_CODE DATA TYPE: A7

The SHODOG_CODE is a coded description of the inventory item. The oode is ued to dencribe the ITM CODE to a further level of detail. If the firet letter of the code is: the tirat letter is a " $R$ " then the code is a cus dascribe inventory iteng which are not tisuves.

The swODOC gloasary it an MRA adaptation of SwOWED and SwOVET. These modical gloasaries use a 5 character code and I character prefix to define ter. thich are organized hierarchically. sNoDoc is escentially pluce of the 5 charecter code. The $6 \mathrm{th}$ position is 0 when the sloooc term is identical to the SHOMED/SNOVET term. MRA specific term have non zero characters in the 6th position of the code. 
Species

Status

Study

Identification

Sub Title
SPECIEs is an alphanumeric code for the species of the animal. NRA assigned SPECIES is an alphanumeric code tor the species of the animal. NRA
codes are numbers between $011^{\circ}$ and $99^{\circ}$ stored as ASCII characters. Codes are

01. - Cania faniliaris, beagle.

02: - Canis faniliaria, st. Bernard.

$03^{\circ}=$ Mus musculus, BNib/c Bd

O1: - Mus muculus, BPM

05. - Mus musculus, C3Hf/Bd

$06^{\circ}$ - Mus musculus, C57BL/68C

STArus is a code describing the role of the person.

Codes are:

\begin{tabular}{|c|c|}
\hline CODE & TRUNS \\
\hline $\begin{array}{l}\mathbf{A} \\
\mathbf{D} \\
\mathbf{E} \\
\mathbf{D}\end{array}$ & $\begin{array}{l}\text { Author } \\
\text { Director } \\
\text { Editor } \\
\text { Other }\end{array}$ \\
\hline
\end{tabular}

DATA TYPE: N2

The STUDY ID in anique NRA identifier of atudy within a laboratory,

The STUDY ID is anique NRA identifier of atudy within a laboratory as ASCII characters.

For the beagles, wudy codes were ssnigned based on the soction number found in eppendix $B$ of Roy Thompen' book. STUDY_ID -00' is used for undesignated controle wile STUDY_ID $99^{\circ}$ is-used for studies not deacribed in Thompen' book.

Por rodente, study codes are assigned based on discussions with the contributing inveatigator. 
The II8BUE_CATEGORY is BMODOC code. The uner normally deals with the trandation.

The TISSUE DOSE (TDOSE) table warizes the dose to onch significant tianue of each aniral. It conteine zero to oeveral rowe por animil. For ancillary animals, where STUDY ID is set to $99^{\circ}$, and for controls, there will be zero row in the TISSUE_DOSE table.

Pending receipt of tiseue spocific dose information, only one row per animal

The tranglated tianue catogorion are:

Body as a whole

Skin and Mrenarie

Bewato and $R E$ System 6 Blood

Lymph nodes

Musculoskeletal oystem

Respiratory aysteo, upper

Digentiver uper (w/o is

Digeative, upper

Urinary Tract, upper
Urinary Tract, lower

Reproductive

Endocrine ayete.

Bervous aystem including ayes

Tissue Quality

WRA PIELD MME: TISS_OUNLITY

DATA TYPE: AI

TISS QUALITY is an alphanueeric sode describing the level of detail wich was applied to the tiasue pathology for this anial. The codes are:

$M$ no tisenus taken.

G = Gross necropuy.

- Bintopathology

- Gross examination of body, head not examined,

- Grose exanination of head, body not examined.

- Bi=topathology of body, head not examined.

- Groas examination of body. Bistopathology of head,

6 - Groan examination of hoad, Bistopathology of body.

Live animal. and thowe with unknown date have IIss_ouniIm set to wurl.

Title 
Volume

NRA PIELD NAME : VOLUME

DATA TYPE: A10

The volune is the volume number assigned to the book or document by the publiaher.

Weight at First Insult
NRA FIELD NAME: WGT_FIRST_INSULT

DATA TYPE: N

The WGT PIRST INSULT is the animal's body weight, in grans, at the firet experiméntal Insult. Unknown or not applicable data are left vull. 
PNL-7877

UC-605

\section{DISTRIBUTION}

No. of

Copies

\section{OFFSITE:}

12 DOE/Office of Scientific and

Technical Information

David A. Smith, Ph.D.

Acting Director of HERD

OHER-ER 72

U.S. Department of Energy (GTN)

Washington, D.C. 20545

Marvin E. Frazier, Ph.D.

U.S. Department of Energy (GTN)

Office of Health and Environmental

Research

ER-72

Washington, D.C. 20545

Michael E. Ginevan, Ph.D.

Deputy Director

Office of Epidemiology and Health

Surveillance

US Department of Energy

Office of Health, EH-42 (GTN)

Washington, D.C. 20545

Otto G. Raabe, Ph.D.

Laboratory for Energy Related

Health Research

University of California at Davis

Old Davis Road

Davis, CA 95616
No. of

Copies

J.A. Louis Dubeau, M.D., Ph.D.

Urological Cancer Research

Laboratory

USC Comprehensive Cancer Center

University of Southern California

Los Angeles, CA 90033-0800

Stephen A. Benjamin, Ph.D.

Director, CRHL

Foothills Campus

Colorado State University

Fort Collins, CO 80523

Scott C. Miller, Ph.D.

Department of Radiobiology

University of Utah

Salt Lake City, UT 84112

Philip R. Watson, Ph.D.

Associate Professor

Department of Chemistry

Oregon State University

Corvallis, OR 97331

Kenneth L. Jackson, Ph.D.

Graduate Program Coordinator

Radiological Sciences Group

SB-75

University of Washington

Seattle, WA 98195

Tom E. Fritz, Ph.D.

Argonne National Laboratory

9700 South Cass Avenue

Argonne, IL 60439 
No. of

Copies

Mr. Don E. Doyle

Argonne National Laboratory

9700 South Cass Avenue

Argonne, IL 60439

Bruce B. Boecker, Ph.D.

Inhalation Toxicology Research

Institute

Lovelace Biomedical \&

Environmental Research Institute

P.O. Box 5890

Albuquerque, NM 87185-5890

Michael Fry, Ph.D.

Oak Ridge National Laboratory

P.O. Box 2009

Oak Ridge, TN 37831

Bruce Carnes, Ph.D.

Argonne National Laboratory

Building 202

Argonne, IL 60439

Patricia W. Durbin-Heavey, Ph.D.

University of California

Lawrence Berkeley Laboratory

1 Cyclotron Road Building \#74-B

Berkley, CA 94720

Ms. Martha E. DeMarre

Section Chief, Coordination and

Information Center

Archives and Research Section

Technical Information Department

Reynolds Electrical \&

Engineering Company

P.O. Box $98521 \quad M / 5548$

Las Vegas, NV 89193-8521
No. of

Copies

Nancy Knight, Ph.D.

American College of Radiology

1891 Reston White Drive

Reston, VA 22091

\section{ONSITE:}

US DOE Field Office, Richlard

PW Kruger

Hanford Environmental Health

Foundation

R Filipy

RL Kathren

33 Pacific Northwest Laboratory

MT Karagianes

JA Mahaffey

JF Park

LG Smith

SK Smith (20)

RC Thompson

CR Watson

RE Weller

Publication Coordination

Technical Report Files (5) 

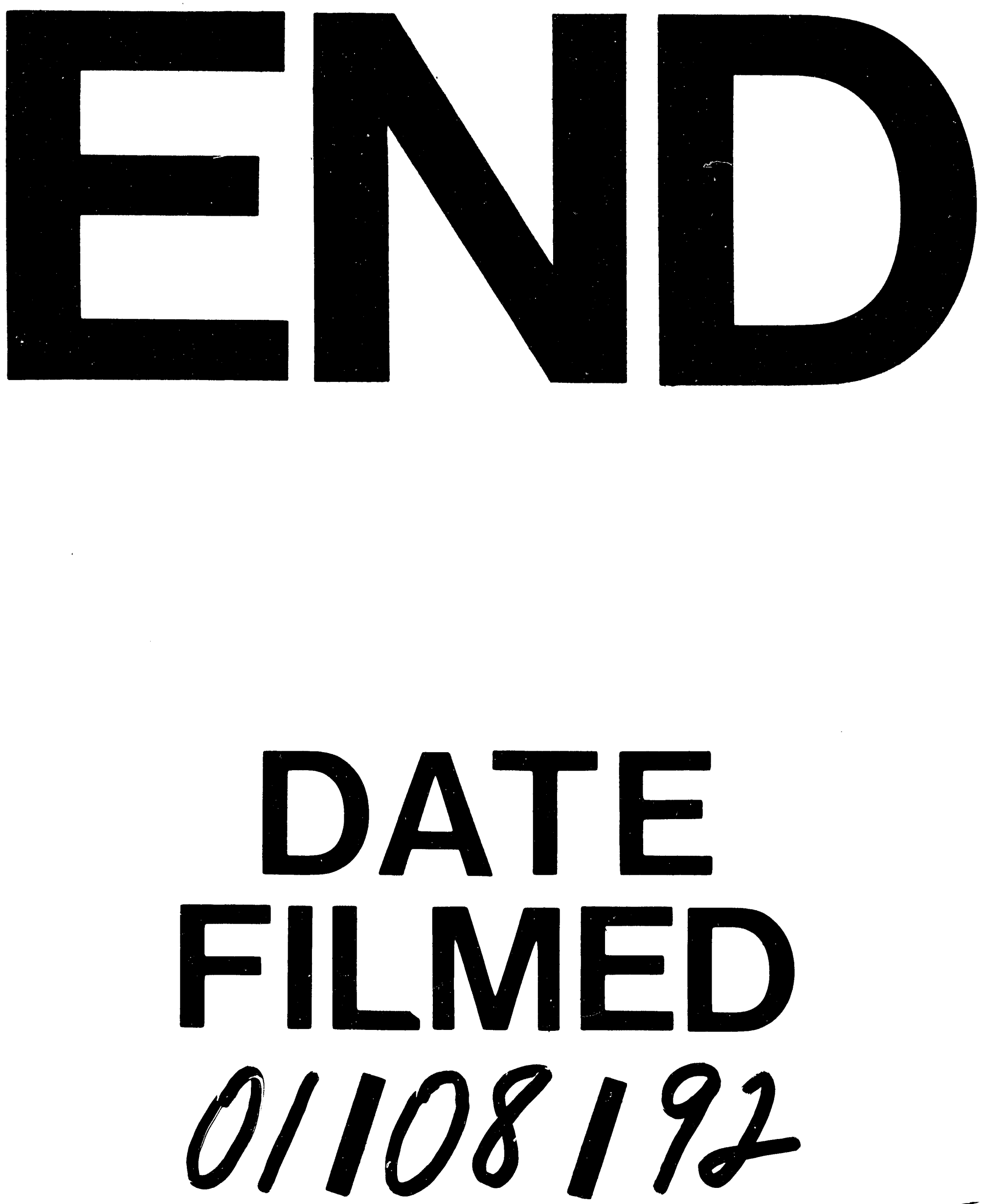
